Florida International University

FIU Digital Commons

FIU Electronic Theses and Dissertations

University Graduate School

$11-5-2012$

\title{
Measuring the Impact of Melaleuca quinquenervia Biochar Application on Soil Quality, Plant Growth, and Microbial Gas Flux
}

Thelma I. Velez

Florida International University, Thelma.Velez@fiu.edu

DOI: $10.25148 /$ etd.FI12120413

Follow this and additional works at: https://digitalcommons.fiu.edu/etd

\section{Recommended Citation}

Velez, Thelma I., "Measuring the Impact of Melaleuca quinquenervia Biochar Application on Soil Quality, Plant Growth, and Microbial Gas Flux" (2012). FIU Electronic Theses and Dissertations. 775.

https:// digitalcommons.fiu.edu/etd/775

This work is brought to you for free and open access by the University Graduate School at FIU Digital Commons. It has been accepted for inclusion in FIU Electronic Theses and Dissertations by an authorized administrator of FIU Digital Commons. For more information, please contact dcc@fiu.edu. 


\title{
FLORIDA INTERNATIONAL UNIVERSITY
}

Miami, Florida

\author{
MEASURING THE IMPACT OF MELALEUCA \\ QUINQUENERVIA BIOCHAR APPLICATION ON SOIL \\ QUALITY, PLANT GROWTH, AND MICROBIAL GAS FLUX
}

A thesis submitted in partial fulfillment of the

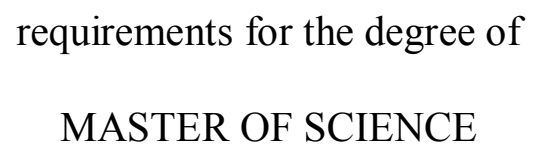

by

Thelma I. Velez 
To: Dean Kenneth G.Furton

College of Arts and Sciences

This thesis, written by Thelma I. Velez, and entitled Measuring the Impact of Melaleuca quinquenervia Biochar Application on Soil Quality, Plant Growth, and Microbial Gas Flux, having been approved in respect to style and intellectual content, is referred to you for judgment.

We have read this thesis and recommend that it be approved.

Leonard J. Scinto

Stewart Reed

Krishnaswamy Jayachandran, Major Professor

Date of Defense: November 5, 2012

The thesis of Thelma I. Velez is approved.

Dean Kenneth G. Furton
College of Arts and Sciences

Florida International University, 2012 


\section{DEDICATION}

I dedicate this thesis to my dog, Oliver. You have made the journey so much more enjoyable. You always make me smile and urge me take the time to enjoy my surroundings, even when there is much work to be done. You are amazing! Ryan

Vogel, you have pushed me from the very beginning to do my best, in my writing, research, and life in general.

My child, you have shown me that carrying and caring for another human being is a far greater task than completing a M.S. thesis. 


\section{ACKNOWLEDGMENTS}

Above all, I wish to give a special thanks to my Mother, Father, Sisters, and Family for nurturing my personal growth and dreams.

I would like to acknowledge the U.S. Department of Agriculture for funding most of my M.S. in Environmental Studies degree and research pursuits. Grants from this agency have allowed me to flourish by providing countless opportunities to demonstrate my capacity at professional conferences.

I wish to thank the members of my committee for their commitment to my academic development. I am grateful for their patience and direction. Dr. Reed's guidance in and outside of the laboratory was immeasurable and indispensable, as was his humor. Dr. Scinto's inquisitive nature encouraged me to dig deeper into my research and myself. Dr. Jayachandran's mentorship was pivotal in directing me toward agriculture, plant, and soil science. He never doubted my ability to carry out this research and always encouraged me to present my work.

I also wish to thank Dr. Mahadev Bhat for consistently pushing me to do my best, in and out of the academic environment. There have also been many friends and peers present throughout this journey; Thanks, Andrew Jungman, Stephany Alvarez- Ventura, Danielle Goveia, Nall Moonilall, and many others who helped me in collecting data or venting frustrations. 


\author{
ABSTRACT OF THE THESIS \\ MEASURING THE IMPACT OF MELALEUCA \\ QUINQUENERVIA BIOCHAR APPLICATION ON SOIL \\ QUALITY, PLANT GROWTH, AND MICROBIAL GAS \\ FLUX \\ by
}

Thelma I. Velez

Florida International University, 2012

Miami, Florida

Professor Krishnaswamy Jayachandran, Major Professor

Biochar has been heralded a mechanism for carbon sequestration and an ideal amendment for improving soil quality. Melaleuca quinquenervia is an aggressive and wide-spread invasive species in Florida. The purpose of this research was to convert M. quinquenervia biomass into biochar and measure how application at two rates ( $2 \%$ or $5 \% \mathrm{wt} / \mathrm{wt})$ impacts soil quality, plant growth, and microbial gas flux in a greenhouse experiment using Phaseolus vulgaris L. and local soil.

Plant growth was measured using height, biomass weight, specific leaf area, and root-shoot ratio. Soil quality was evaluated according to nutrient content and water holding capacity. Microbial respiration, as carbon dioxide $\left(\mathrm{CO}_{2}\right)$, was measured using gas chromatography. Biochar addition at $5 \%$ significantly reduced available soil nutrients, while $2 \%$ biochar application increased almost all nutrients. Plant biomass was highest in the control group, $\mathrm{p}<0.001$. Initial $\mathrm{CO}_{2}$ flux decreased significantly in both biochar groups, but reductions were not long term. 


\section{TABLE OF CONTENTS}

CHAPTER

PAGE

I. INTRODUCTION ........................................................... 1

II. BACKGROUND ........................................................... 3

Evolution of Agriculture ........................................... 3

Agriculture's Downside............................................. 4

Greenhouse Gas Emissions................................................ 5

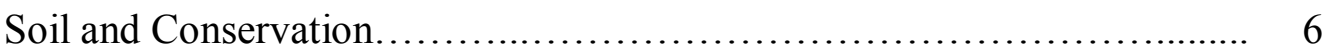

Invasive Species ...................................................... 9

Biochar........................................................ 11

Florida Agriculture and Soil ...................................... 13

III. STATEMENT OF PURPOSE.............................................................. 15

Research Objectives............................................. 15

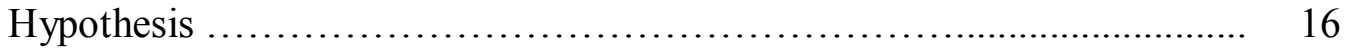

Importance of the Study .......................................... 16

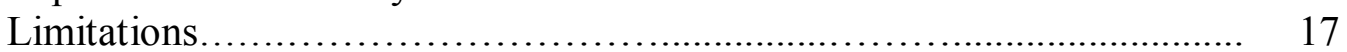

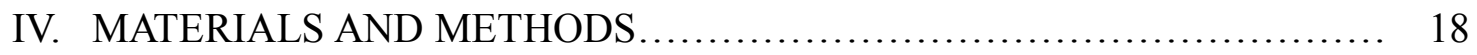

Biochar Processing .............................................. 18

Soil Processing.................................................. 20

Seed Selection.................................................... 21

Experimental Design............................................ 21

Biochar Analysis .......................................................... 22

Soil Analysis ............................................................ 23

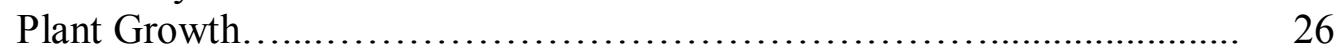

Microbial Gas Flux........................................................ 26

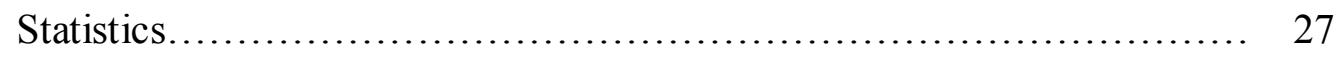

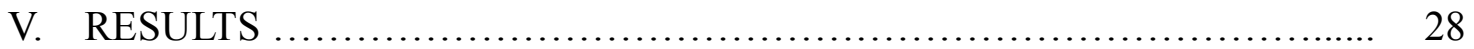

Biochar Analysis .................................................. 28

Seed Germination................................................... 28

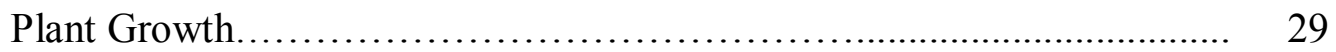

Microbial Gas......................................................................... 4

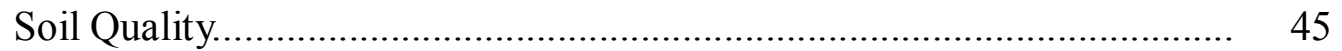

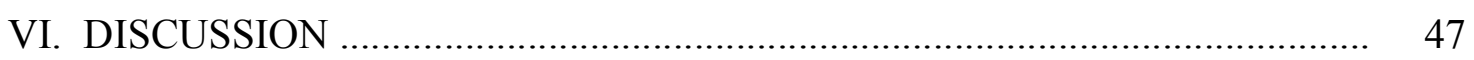

Biochar and Germination........................................................................ 47

Biochar and Plant Growth................................................................... 48

Biochar and Soil Quality.............................................. 49

Biochar and Soil Respiration...................................... 51

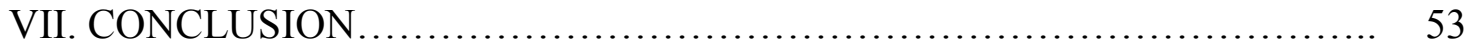




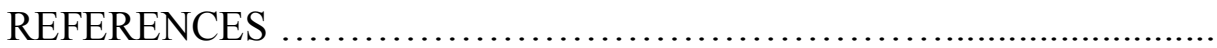




\section{LIST OF FIGURES}

FIGURE

PAGE

1 a. Steel drums used to process biochar............................... 19

$1 \mathrm{~b}$. Steel drum system used to process biochar with modified top.............. 19

1 c. Complete steel drum system for biochar processing with retort.............. 19

2. Germination of Phaseolus vulgaris L. seeds for control, $2 \%$ and $5 \%$ biochar

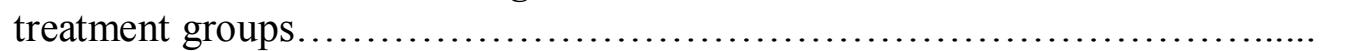

3. Above ground Phaseolus vulgaris L. biomass (shoot) means for all treatments; dry weight $(\mathrm{g})$

4. Phaseolus vulgaris L. fruit production for all treatment groups, measured as pod dry weight $(\mathrm{g})$

5. Mean pod length ( $\mathrm{mm})$ from Phaseolus vulgaris L. plants at harvest for Control, $2 \%$ and $5 \%$ biochar treatment groups.

6. Side by side comparison of above ground biomass from a control plant and $2 \% \mathrm{BC}$ treated plant.

7. 5\% BC treated Phaseolus vulgaris L. Note: leaf discoloration and stunted growth ....

8. Phaseolus vulgaris L. Control plant. Note: green healthy leaves, no discoloration.

9 a - b. Healthy above ground biomass harvested from two Phaseolus vulgaris L. plants in the control group...................................

$9 \mathrm{c}-\mathrm{d}$. Above ground biomass harvested from two Phaseolus vulgaris L. plants in the $2 \%$ BC group; note small pod size and discoloration...

9 e - f. Above ground biomass harvested from two Phaseolus vulgaris L. plants in the 5\% BC group; note small pod size and discoloration.

10. Mean change in Phaseolus vulgaris $\mathrm{L}$. height $(\mathrm{mm})$ from $\left(\mathrm{t}_{\varnothing}\right)$ to $\left(\mathrm{t}_{\mathrm{f}}\right)$ for all treatment groups 


\section{LIST OF FIGURES}

FIGURE

PAGE

11. Phaseolus vulgaris L. growth (mm) from $\left(\mathrm{t}_{\varnothing}\right)$ to $\left(\mathrm{t}_{\mathrm{f}}\right)$ for all treatment groups.

12. Mean Leaf Area $\left(\mathrm{cm}^{2}\right)$ of Phaseolus vulgaris L. for all treatment groups measured with a portable leaf area meter LICOR 3100.

13. Phaseolus vulgaris L. Specific Leaf Area means $\left(\mathrm{cm}^{2} \mathrm{~g}^{-1}\right)$

14. Phaseolus vulgaris L. Root-Shoot Ratio for Control, $2 \%$ and $5 \%$ biochar treatment plants.

15. Phaseolus vulgaris L. plant roots for the Control group....

16. Phaseolus vulgaris L. plant roots for $2 \% \mathrm{BC}$ treatment group 40

17. Phaseolus vulgaris L. plant roots for the 5\% BC treatment group.

18. $\mathrm{CO}_{2}$ production means from Control, $2 \%$ and $5 \% \mathrm{BC}$ treatment groups from $\left(t_{\varnothing}\right)$ through $\left(t_{f}\right)$

19. $\mathrm{CO}_{2}$ flux from soils at $\left(\mathrm{t}_{\varnothing}\right)$ for Control, $2 \%$ and $5 \% \mathrm{BC}$ treatment groups prior to planting.

20. $\mathrm{CO}_{2}$ flux from soils at $\left(\mathrm{t}_{1}\right)$ for the Control, $2 \%$ and $5 \% \mathrm{BC}$ treatment groups.

21. $\mathrm{CO}_{2}$ flux from soils at $\left(\mathrm{t}_{2}\right)$ for the Control, $2 \%$ and $5 \% \mathrm{BC}$ treatment groups 


\section{INTRODUCTION}

Prior to the industrial revolution, the global population was 700 million people (Chu 2012). Since then the population has risen, from two billion in 1960 to greater than seven billion today (CIA Factbook 2012). Natural resources have become exceedingly scarce as demand for biotic and abiotic resources, such as food, timber, water, land, and energy increased exponentially over the last one hundred and fifty years. Humanity has reached a pivotal point in Earth's history and the planet's carrying capacity is now of major concern (Arrow et al. 1995).

Human growth and societal development has resulted in severe environmental degradation on a global scale. A major contributing factor to this degradation is the conversion of land for agricultural use (IPCC 2007). Invasive species transported by humans have become an additional paramount problem. Not only are ecosystems being destroyed, but the services they provide are as well (Costanza et al. 1997). Anthropogenically induced climate change and biodiversity loss are no longer questionable theories (MEA 2001). Humans are changing global ecosystems drastically.

Greenhouse gas emissions have skyrocketed above historical record highs. The overload and leaching of synthetic fertilizer has altered the planet's nitrogen and phosphorus cycles, leading to eutrophication of waterways (WRI 2012). Tillage techniques employed in conventional agriculture are known to cause severe soil erosion, water runoff, and overall reduction of integral soil biota (Reicosky et al. 1995). As soil quality continues to decline, many wonder if agriculture can provide the yields needed to feed the growing population. 
The need for land, water, and food cannot be ignored. It is time to question whether agricultural supply can meet current and future demand without further exacerbating the problem. As agricultural land accounts for $40-50 \%$ of the terrestrial surface (FAOSTAT 2009), it is only fitting the agricultural sector take action to prevent and reduce environmental stress. Many researchers are now focusing on ways to mitigate the devastation caused by human pursuits. In the face of exponential population growth, it is crucial to find newer sustainable technologies to deal with mounting problems.

Biochar has the potential to become a new technology employed in agricultural systems. Biochar is a compound obtained through pyrolysis of biomass, or biowaste. The fertile "Dark Earth," or "Terra Preta" found in the Amazon is what stimulated academic interest in biochar (Sombroek et al. 2003). Biochar is claimed to be a mechanism for carbon sequestration and an ideal amendment for improving soil quality in agricultural settings (Lehmann 2007; Jha et al 2010.) Unfortunately, very little is known about the interaction of biochar in differing soil types.

In south Florida, several plant species have come to dominate and severely alter delicate ecosystems. Melaleuca quinquenervia has been characterized as one of the most aggressive and wide-spread invasive species by the Florida Exotic Pest Plant Council. Invasive species can be used as an inexpensive form of biomass to produce biochar. It is the objective of this study to determine whether biochar produced from $M$. quinquenervia is suitable and sustainable for south Florida agricultural use. 


\section{BACKGROUND}

\section{The Evolution of Agriculture}

Prior to the mid eighteenth century agriculture primarily consisted of a mosaic of smallscale family farms. Food production was intended for local consumption. Intensive manual labor was alleviated by draft animals. Crops were selected based on regional climate and a variety of crops were grown to ensure proper nutrition for the people and the soil. Today, traditional farming comprises only a small percentage of global food production.

The industrial revolution impacted agricultural techniques drastically. New machinery was developed to reduce the labor of men and women. Large tractors and soil tillers were built to plow through soil. Mechanized irrigation meant many farmers no longer had to spend hours watering crops. In short, the need for manual labor decreased wherever new technologies were employed (Petrini 2005).

The transition from traditional labor to mechanized labor allowed larger farms to flourish. Small farms that could not compete were forced out of the sector (Gleissman 1998). In addition, increased access to off-farm jobs and higher education led many families to give up farming altogether. Over time, large corporations began controlling many aspects of agriculture, from seed production and feedstock, to nutrient and pesticide input. Today, the prevailing agricultural system is comprised of industrial farms, also known as conventional farms (Rekha and Naik 2006).

As globalization increased, so did access to new food items. Crops were planted in regions they never before had been sown, regardless of climate. Biodiversity of crop species decreased as farms focused most of their energy on cereal crop species, such 
as wheat, rice, and corn (Gleissman 1998). The green revolution in the late 1960's brought high yield crop varieties, hybridized seeds, and disease and pest resistant species, all of which were seen as significantly superior to traditional crops species (Feder and O’Mara 1981).

In less than one hundred years, humans shifted from small scale agricultural production using draft animals, man power, and ecologically sound soil amendments, such as manure, to conventional agricultural practices. Worldwide, millions of hectares of land were converted to single species crop plantations, requiring heavy amounts of irrigation, tillage, and synthetic fertilizer (Gleissman 1998). While technological advances have improved agricultural production, in terms of quantity, they are not without costs.

\section{Agriculture's Downside}

The methods employed in conventional agriculture decimate global nutrient cycles and disturb the natural regime. Intense land management and cultivation leads to severe soil degradation, and on a larger scale, the destruction of entire ecosystems. To begin, land conversion leads to deforestation, severe habitat fragmentation, and overall biodiversity loss. Once land is converted, tillage techniques employed in conventional agriculture are known to cause severe soil erosion, water and nutrient runoff, and drastic reductions in soil biota. Furthermore, both conversion and tillage are closely linked to terrestrial carbon losses, making them sources of atmospheric carbon.

Water consumption has doubled in the last sixty years, and $70 \%$ of water is used in agriculture (MEA 2005). Inefficient and intensive irrigation is yet another issue plaguing conventional farms, but perhaps not as serious as the overuse of 
petroleum-based, synthetic inputs. Agriculture today is heavily reliant on energy in the form of fossil fuels to run heavy machinery and produce synthetic inputs. Synthetic inputs pollute waterways and soil. Since 1960, nitrates found in ecosystems have doubled and phosphates have tripled (Petrini 2005). According to Janzen and Desjardins (1999), about $1 \mathrm{~kg}$ of carbon dioxide $\left(\mathrm{CO}_{2}\right)$ is emitted in the manufacture and transport of $1 \mathrm{~kg}$ of nitrogen fertilizer. Not only does the technology itself do harm to the system as whole, but the mode of obtaining and running the technologies also contributes stress to the environment.

\section{Greenhouse Gas Emissions}

The Intergovernmental Panel on Climate Change (IPCC) summary for policy makers stated in 2001 that carbon dioxide is a significant anthropogenic greenhouse gas whose increases are linked primarily to fossil fuel use and land conversion. According to a climate change report, annual $\mathrm{CO}_{2}$ emissions grew by about $80 \%$ between 1970 and 2004 (IPCC 2007). According to Baumert et al. (2005), agriculture accounts for approximately $15 \%$ of the total global greenhouse gas emissions. However, this is only a calculation for direct emissions, such as nitrous oxide, carbon dioxide, and methane. Indirect emissions from agriculture are estimated to be an additional $12 \%$ (Scialabba et al. 2010). Indirect emissions come in the form of inputs, machinery, irrigation, and land conversion. Factoring this $12 \%$ in means that agriculture today contributes to over a quarter of the global greenhouse gas emissions.

Until the 1970's more $\mathrm{CO}_{2}$ had been released into the atmosphere from agricultural activities than from fossil fuel burning (Desjardins 2005.) According to Houghton 
and Hackler (2000), between 1850 and 1990, the net flux of carbon between the terrestrial biosphere and the atmosphere from changes in land cover and land use was $124 \mathrm{Pg} \mathrm{C}$. Another estimate for the same period quoted total carbon loss from anthropogenic land changes to be around $200 \mathrm{Pg} C$ (DeFries et al. 1999.) A study done in 1995 placed the annual net release of carbon from agriculture at $0.8 \mathrm{Pg} \mathrm{C}$, which equated to $14 \%$ of fossil fuel emissions at the time of the study (Schlesinger 1997). Clearly, there is a significant impact from agriculture on greenhouse gas emissions.

\section{Soil and Conservation}

Soil does much more for the biosphere than simply provide a medium for plant growth. Healthy, fertile soil provides a habitat for organisms to thrive. Soil organisms regulate the flow of energy through the soil (Doran and Zeiss 2000). Soil macro fauna, including earthworms, arthropods, and others, are integral to soil creation (Coyne 1999). However, it is the microorganisms, such as bacteria, protozoa, fungi, and actinomycetes that play the largest role in soils of every ecosystem (FAO 2010).

Microorganisms are responsible for many of the conversions of organic and inorganic matter in soil (Karlen et al. 1997). Most nutrient cycling occurs through the work of various soil microbes. Transformation of carbon, nitrogen, phosphorus, sulfur, and other elements is crucial to plant nutrition and maintaining overall environmental quality (USDA-NRCS 2001). Understanding the function of soil biota is critical for any plan aimed at mitigating environmental degradation and improving soil quality. 
Soil contains several horizons; the zones with the highest microbial activity are located nearest to the surface and are known as the O and A horizons (Coyne 1999). Even when the $\mathrm{O}$ and $\mathrm{A}$ horizons are not deep, they contain most of the soils organic matter (Coyne 1999). Soil organic matter is made up of decomposed leaf litter and other decaying plant tissue, humus, animal remains, and soil biota. When soil is managed intensively through the use of heavy machinery, the organic matter it contains suffers, decreasing soil fertility (Gleissman 1998).

Tillage ultimately results in soil biota losing the habitat in which they can function optimally; the organisms begin to die and biomass slowly decays (Oades 1993). The soil loses a portion of its capacity to aggregate and store water and nutrients, such as nitrogen and phosphorus. The outcome is a dry soil requiring heavy fertilizer inputs and more intense irrigation than needed. Conventional agriculture does not focus primarily on enhancing soil quality; the focus is often on production quantity.

Soil is a finite resource, making conservation integral to human and ecosystem health. Annual soil loss to erosion far exceeds soil creation. In North America, South America, and Africa, soil lost to erosion ranges five to ten tons per hectare; in turn, soil is created at a mere rate of one ton per hectare annually (Gleissman 1998). When soil organic matter dwindles away and crops are continuously sown, the need for more inputs rises. Before conventional agriculture became main stream, soil was a carbon sink. Sustainable agriculture is a method of producing food which minimizes soil loss through reduced or no tillage and without the heavy use of synthetic inputs. By building up soil organic matter again, sustainable agriculture could sequester carbon at greater levels. Degraded croplands make up approximately 100 million (M) 
hectares (ha) of the $250 \mathrm{M}$ ha severely degraded lands worldwide (Dulal 2011). Approximately 600 million to 1 billion metric tons of carbon can be sequestered through restoration of degraded soils every year (Laland Bruce 1999). In addition to sequestering carbon, the soil also will improve the habitat for organisms which, as stated earlier, are the primary mechanism for conversion of organic and inorganic matter. In a study by Kern and Johnson (1993), they found that a no till practice was the only practice that could offer substantial carbon sequestration (Kern and Johnson 1993.) Smith et al. (2000) used Kern and Johnson's work to implement a study in Canada using models for calculating soil organic carbon content in till and no-till cropping systems over a thirty year time frame (1970-2000.) Their results show that complete and partial adoption no tillage practices can significantly increase the soil organic carbon content and sequestration capacity. They estimated the rate of carbon changed from $-67 \mathrm{~kg} \mathrm{C} / \mathrm{ha}$ in 1970 to $-39 \mathrm{~kg} \mathrm{C} / \mathrm{ha}$ in 1990; by 2000 the soils ceased to be a carbon source (Smith 2000). Lal and Bruce (1999) estimated the total sequestration potential of the world cropland is about $0.75-1.0 \mathrm{Pg} \mathrm{C} / \mathrm{yr}$, which is equivalent to about $50 \%$ of annual emissions from deforestation and other agricultural activities.

Sustainable practices, such as conservation tillage or no tillage can help protect soil resources. Reduction or elimination of synthetic fertilizers and pesticides help clean up waterways and ecosystems. The importance of organic food production cannot be stressed enough. While many argue organic food systems will never feed the growing population, neither can conventional food systems if human technology continues to erode and pollute finite resources. Agricultural technology must improve 
production in an ecological sound way. New amendments must conserve soil, reduce pollutants, and minimize greenhouse gas emissions

\section{Invasive Species}

Globally invasive species have become a serious problem. An invasive species is an introduced species causing ecological and/or economical harm to a native ecosystem. These species alter ecosystem functioning and inhibit the proliferation of native species. Noxious plant species introductions are usually facilitated by human transport for ornamental or agricultural reasons (Langeland et al. 1997).

In southern Florida several plant species have come to dominate and severely alter delicate ecosystems. Melaleuca quinquenervia has been characterized as one of these invader species. It is listed on the Federal Noxious Weed List, as well as, Florida's Noxious Weed List and Florida's Prohibited Aquatic Plant List, making it illegal to import, introduce, transport, possess, cultivate, move or multiply without a permit (IFAS 2012) It has vigorously spread throughout much of the delicate Everglades ecosystem and throughout many urban areas as well. Melaleuca quinquenervia can become established in terrestrial or aquatic areas with ease (IFAS 2012). Once established, it forms dense forests displacing native vegetation, altering the entire ecosystem (Langeland et al. 1997).

Melaleuca quinquenervia, a native of Australia, is an evergreen tree of the family Myrtaceae. It can grow to well over thirty meters tall and produces a large quantity of seeds, easily dispersed by wind (Dray et al. 2006). Early horticultural records date six major introductions, the first being in the late 1880's as an ornamental 
distributed by Royal Palm Nursery in Manatee, Florida (Dray et al. 2006). The population on the East coast of Florida has been attributed to John Gifford, who received approval from the US Department of Agriculture. It was later spread aerially to stimulate forest growth in south Florida and then used by the US Army Corps of Engineers as a barrier to prevent flooding from the over flow of water in Lake Okeechobee (IFAS 2011).

By the early 1990's, M. quinquenervia was identified as an invasive noxious weed. In 1994 it was estimated to have infested over 200,000 hectares in south Florida (Langeland and Cherry 2008). Removal of M. quinquenervia populations is a labor intensive operation that has been pioneered by the National Park Service, the US Fish and Wildlife Service, South Florida Water Management District (SFWMD) and the US Army Corps of Engineers. Mechanical Removal costs approximately $\$ 2,080$ per hectare and ground herbicide application costs $\$ 1,330$ per hectare (Van Driesche et al 2002). In a recent estimate, the SFWMD alone spent $\$ 13$ million from, 1991-1998 to control M. quinquenervia in the Water Conservation Areas just south of Lake Okeechobee (Van Driesche et al. 2002).

Many sectors capitalize on the rapid expansion of M. quinquenervia. Some lumber, chip, pulp, and mulch companies have been utilizing M. quinquenervia wood in place of the native cypress tree, Taxodium distichum. GoMulch, Inc., located in Florida has been producing Melaleuca mulch as an alternative to cypress mulch for many years. The company has removed thousands of hectares of $M$. quinquenervia forests for public and private entities. In addition to cost, a major problem when dealing with invasive species has to do with (a) removal, or extraction, and (b) what to do with waste. Should 
biochar application to soil yield promising results, there may be incentive to deal with these noxious plants in a profitable way. With a state of the art facility, it would be simple for companies similar to GoMulch, Inc. to expand their services to produce biochar from a product they already obtain daily. Melaleuca quinquenervia biochar must first prove successful for agricultural use in south Florida.

\section{Biochar}

Biochar has been a topic of growing interest in the scientific community. Biochar is a compound obtained through pyrolysis of biomass or biowaste. In the absence of oxygen, complete combustion (to $\mathrm{CO}_{2}$ ) ceases and what remains is a relatively inert compound known as black carbon, or biochar. In the Amazon, black carbon has been

utilized for over two thousand years (Kammann et al. 2012). A practice of slashing and charring forest trees, and other biomass, led to the development of a dark, fertile soil known as "Terra Preta" (Sombroek et al. 2003). In Amazonian soils, biochar has acted as a soil conditioner which has improved nutrient efficiency and other soil properties (Novak et al 2009).

Biochar is considered extremely stable and may remain in soils for long periods of time, estimated between one hundred to several thousand years (Novak et al. 2010). Experiments carbonizing poultry litter, pecan shells, peanut shells, switchgrass, compost, and various types of wood have proved to be rather successful, yet much still remains unknown about soil-biochar interaction (Jha et al. 2010; Novak et al. 2009; Smith 2010). Biochars vary in physical composition depending of feedstock, pyrolysis temperature, and method of pyrolysis (Rogovska 2009). A biochar produced 
at higher temperatures can yield a finished product with greater surface area, cation exchange capacity, and porosity, allowing for greater $\mathrm{C}$ sequestration and longer mean residence times. Biochars produced at lower temperatures have been considered more suitable as soil conditioners. Several recent studies have shown biochar addition can either directly or indirectly increase available macro and micro-nutrients in soil.

However, it is important to understand that the addition of biochar will not always result in a net benefit to plant productivity (Warnock et al 2007.)

Biochar can be manufactured using differing methods to achieve specific goals. High surface area and porosity in certain biochars have the potential to immobilize nutrients, thereby limiting what is accessible to the plant. Yet, this characteristic has beneficial uses. Certain biochars have been engineered to aid in soil nutrient immobilization and used as sorbents for removal of organic contaminants, as well as, cadmium and zinc (Beesley et al. 2011; Chen et al. 2011.) Research by Vaccari et al. (2011) suggests slow oxidization of biochar in soil can result in the formation of carboxylic groups and better cation exchange capacity, yielding soils with enhanced capacity to retain nutrients over time Altered cation exchange capacity resulting from biochar amendments has also been shown to have an impact on the cycling of nitrogen in soil by influencing nitrification rates, adsorption of ammonia, and increases in ammonium storage (Clough and Condron 2010).

Soil organism activity is crucial to maintaining soil structure and enhancing plant development. A study by Busch et al. (2012) showed that earthworms actually preferred soil amended with peanut hull biochar, but avoided soil amended with another form of charred biomass. Biochar has been documented to positively affect 
mycorrhizal associations when applied to soils (Warnock et al. 2007.) Research suggests there are several mechanisms that contribute to altered mycorrhizal fungi activity in soils with biochar amendments.

A study by Zhang et al. (2009) on biochar application to soils yielded promising results for $\mathrm{C}$ stock enhancement. In some cases, biochar related reductions in carbon dioxide are short lived. It has been suggested that biochar improves soil aeration thereby decreasing anoxic conditions in soils (Van Zwieten et al. 2010). Biochar applications were found to increase $\mathrm{CH}_{4}$ uptake by Chan (2008); this uptake was attributed to better soil aeration. Biochar production can be relatively self sufficient in terms of energy requirements and can yield a surplus of energy in the form of heat or biofuel, which can be utilized for energy conversion (Matovic 2011.)

\section{Florida Agriculture and Soil}

South Florida soil is usually highly carbonatic with high calcium content. These soils tend to be alkaline, with $\mathrm{pH}$ levels as high as 8.5 . The predominance of limestone, or calcium carbonate $\left(\mathrm{CaCO}_{3}\right)$, underlying the soil has resulted from thousands of years of marine deposition. Even soil that is not calcareous can become calcareous if irrigated using the Floridian aquifer, as the water contains traces of dissolved $\mathrm{CaCO}_{3}($ Obreza 1993).

Plants grown in calcareous and alkaline soils must adapt to adverse conditions. Agricultural producers in southeast Florida must find ways to ammend the soil. The $\mathrm{pH}$ of a soil is critical in nutrient sorption and dissolution (Eckhard). The presence of calcium carbonate both directly and indirectly affects the availability of many critical 
nutrients, such as nitrogen $(\mathrm{N})$, phosphorus $(\mathrm{P})$, potassium $(\mathrm{K})$, magnesium $(\mathrm{Mg})$, sodium $(\mathrm{Na})$, iron $(\mathrm{Fe})$, zinc $(\mathrm{Zn})$, copper $(\mathrm{Cu})$, and manganese $(\mathrm{Mn})$. Plants in alkaline soils usually display iron deficiencies, such as chlorosis, or impaired root growth resulting from zinc deficiencies. 


\section{STATEMENT OF PURPOSE}

\section{Research Objectives}

The objective of this research is to convert M. quinquenervia woody biomass into biochar and explore how application of the biochar at two rates impacts soil quality, plant growth, and microbial gas flux in a sustainably managed soil. Locally produced compost serves as soil fertilizer; no synthetic fertilizers or synthetic pesticides have ever been applied. The soil was either used unamended as a control or amended with M. quinquenervia biochar at $2 \%$ and $5 \%$, by mass, to provide a growing medium for snap bean (Phaseolus vulgaris L.). Using several parameters, I aim to compare control and treatment groups to determine how biochar impacts soil quality, soil respiration in the form of carbon dioxide, and overall snap bean production. Snap beans are commonly grown in southeastern Florida. By utilizing invasive species for biochar production, I hope to find a viable and productive use for this immense waste stream.

\section{Specific Objectives}

1) To evaluate the impact of $M$. quinquenervia biochar application on soil quality by analyzing soil available macro and micro-nutrient content and water holding capacity.

2) To determine if $M$. quinquenervia biochar application is beneficial for snap beans grown in southeast Florida by measuring plant productivity in terms of pod yield, plant height and weight, leaf area, and root shoot ratio, over one growing season in a greenhouse experiment.

3) To evaluate if $M$. quinquenervia biochar application in soil resuces microbial gas flux, by analyzing soil samples, for $\mathrm{CO}_{2}$, from the greenhouse experiment 
4) To determine which treatment of biochar in soil is optimal for improving soil fertility, snap bean production, and reducing $\mathrm{CO}_{2}$ emissions.

\section{Hypothesis}

The application of M. quinquenervia biochar at a low rate will be beneficial for soil quality, plant growth, and $\mathrm{CO}_{2}$ reduction. The higher application rate will harm plant growth, but further reduce $\mathrm{CO}_{2}$ emissions.

\section{Experimental Hypothesis}

1) The application of M. quinquenervia biochar will reduce available nutrients in the soil.

2) M. quinquenervia biochar application will result in greater water holding capacity.

3) M. quinquenervia biochar treatment at 5\% will lead to lower plant productivity, than the $2 \%$ treatment.

4) M. quinquenervia biochar mixed with soil will yield lower $\mathrm{CO}_{2}$ release than control soil.

\section{Importance of the Study}

The role of agriculture in sustaining an ever growing population is pivotal. Without the underlying goal of maintaining ecological stability, advances in agricultural production cannot be made. Should $M$ quinquenervia biochar application to agricultural soil yield promising results for plant growth, soil improvement, and carbon dioxide emission reduction, incorporation of this amendment can alleviate some of the 
stresses caused by an already failing food system. The use of local, urban garden soil for this experiment highlights the importance of enhancing food production in urban, community based and managed gardens. The current global food system has not only resulted in mass production of unsustainably grown food, but also a loss of power on the consumer end. Huge corporations select which items to invest in and local consumers have little choice but to purchase these items in chain supermarkets. Expanding local food systems empowers a community and provides added food security, while increasing natural areas and biodiversity. Biochar has the potential to revolutionize food production.

\section{Limitations}

This was a potted plant experiment carried out in a greenhouse in an effort to reduce environmental variability. Had this experiment been carried out in the field, unpredictable weather, pest infestation, and disease could have influenced the results. Unfortunately, the setting also limits the real interaction of soil organisms. The cycling of nutrients that occurs through both macro and micro-organisms is not fully captured in this experiment. As this study was meant to mimic a sustainably managed garden, the lack of naturally occurring soil organisms could have inhibited the decomposition process and the mineralization of important nutrients. In addition, there was no way to tell if certain soil macro fauna avoid biochar treated soil in this study. 


\section{MATERIALS AND METHODS}

\section{Biochar Processing}

Melaleuca quinquenervia was collected near Tamiami Trail and SW 147 Ave, Miami, Florida $\left(25^{\circ} 45^{\prime} \mathrm{N} 80^{\circ} 26^{\prime} \mathrm{W}\right)$. Three live trees were collected. Each tree was approximately 10 meters in height with diameter at breast height ranging from $11 \mathrm{~cm}$ to $14 \mathrm{~cm}$. Once cut, branches and leaves were removed and the trunk was sawed into $20 \mathrm{~cm}$ to $26 \mathrm{~cm}$ pieces. The soft tree bark was removed by hand and wood was air dried in a laboratory for three days. The wood was then oven dried at $80{ }^{\circ} \mathrm{C}$ for 24 hours (Thermo Electron, Texas).

The remaining biomass was processed in closed, cylindrical metal containers at $350^{\circ} \mathrm{C}$ in an Isotemp muffle furnace for 7 hours (Fisher Scientific, New Jersey). Nine consecutive batches were processed over a six day period. Once removed from the furnace, the biochar was doused with distilled deionized water to prevent complete combustion. The biochar was then dried at $80^{\circ} \mathrm{C}$ until weight was constant. All processed batches were combined. The biochar was pulverized, homogenized, and sieved using No. 25 Fisher Scientific sieve.

In a preliminary trial, the biochar was produced using a drum method utilizing three invasive plant species for biomass, Schinus terebinthifolius, Melaleuca quinquenervia and Casuarina equisitifolia. The drum barrel method was chosen because it is readily available to farmers and is easy to implement. A large, 55 gallon steel barrel was filled with biomass to be charred. The barrel had roughly fifty to one hundred small holes at the bottom to allow for minimal air flow. A fire is initiated in the drum to begin the combustion process, and a modified top is placed on the 
drum as an opening for smoke and airflow. A retort is set up by placing a metal cylindrical chute over the opening on the large barrel to assist with airflow and smoke removal (Figures 1 a-c). After several hours, the finished product was doused with water to prevent complete combustion.

Figure 1 a

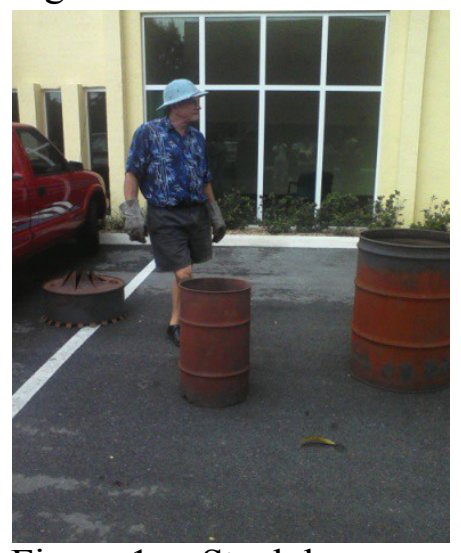

Figure $1 \mathrm{~b}$

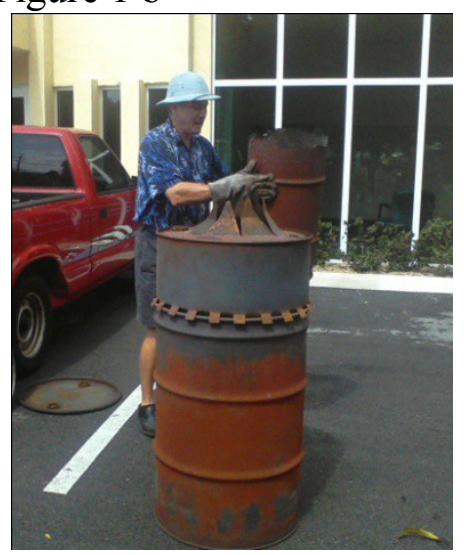

Figure 1c

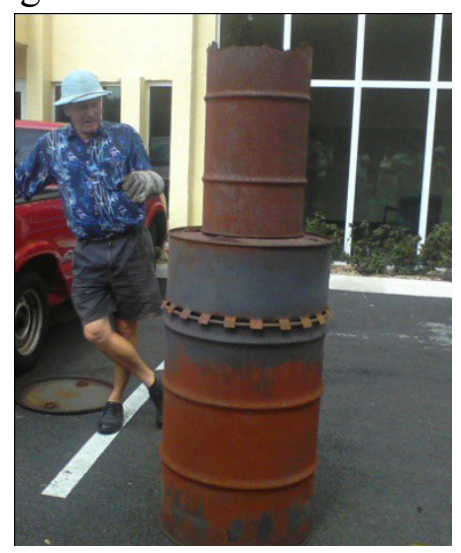

Figure 1 a. Steel drums used to process biochar.

Figure $1 \mathrm{~b}$. Steel drum system used to process biochar with modified top.

Figure 1 c. Complete steel drum system for biochar processing with retort.

After preliminary trials using the drum method, it became apparent biochar produced in this manner was not ideal for amending southeastern Florida soil. Biochar $\mathrm{pH}$ was measured using an electrode $\mathrm{pH}$ meter in a $1 \%$ suspension of pulverized biochar with deionized water, heated for fifteen minutes at $90^{\circ} \mathrm{C}$ (Novak; Pers. Corr. 2011). The finished product yielded biochar with extremely high $\mathrm{pH}$ values. Melaleuca quinquenervia ranged from 9.24 to 10.12 , S. terebinthifolius ranged from 9.84 to 10.56 , and C. equisitifolia ranged from 10.26 to 11.12 . The barrel method had temperatures exceeding $600^{\circ} \mathrm{C}$ and was not deemed adequate for this study. The soil in South Florida has an alkaline $\mathrm{pH}$. Therefore, an attempt was made produce a biochar with a more neutral $\mathrm{pH}$. After discussing temperature effect on biochar $\mathrm{pH}$ 
with researchers in the USDA Agricultural Research Station (Coastal Plains) biomass was processed in a muffle furnace at $350{ }^{\circ} \mathrm{C}$ in order to reduce the $\mathrm{pH}$. For the revised method, M. quinquenervia was selected from the initial trial because that feedstock had the lowest $\mathrm{pH}$. The $\mathrm{pH}$ of the biochar from the $350{ }^{\circ} \mathrm{C}$ furnace method did not exceed 8.32 .

\section{Soil Processing}

Soil was obtained locally from the Organic Garden at FIU. The garden was established in2006 by the Agroecology Program for student experiential learning. The land is a sustainably managed area comprised of eight to twelve independent plots ranging in size from 2 square meters to 10 square meters. The plots are all raised $20 \mathrm{~cm}$ to $30 \mathrm{~cm}$, as the presence of limestone, or calcium carbonate, makes it difficult to dig deep trenches. Compost is produced on site using the hot composting method. Every plot is amended with different batches and amounts of compost.

At the time of collection, some areas had been cover cropped with clover or rye, while other plots had vegetables growing year round. Surface soil was collected down to $25 \mathrm{~cm}$ depth from random areas in every plot to reduce bias. The collected soil was homogenized to create a uniform blend. Once homogenized, the soil was air dried for three weeks in a laboratory. The soil was not sterilized to avoid lysing important microorganisms for nutrient cycling. Soil and biochar were weighed in order to amend soil with $2 \%$ or $5 \%$ biochar addition by mass, relative to soil weight. Biochar was thoroughly mixed into soil and stored for 3 weeks in a laboratory. On March 18, 2012, soil was potted. Approximately 2,450 g of soil was lightly packed into each pot. 


\section{Seed Selection}

The selection of Phaseolus vulgaris L., snap bean, as the experimental crop was determined by the duration of the south Florida growing season, suitability for the region, and short time to harvest (under 65 days). Snap bean is a principle vegetable in southeastern Florida production grown by both organic and conventional farms. Snap beans can tolerate moderate levels of heat and soil $\mathrm{pH}$ up to 8.3. A bush bean variety was selected over a pole bean variety as a result of limited space in the greenhouse and difficulty measuring overall plant height in the pole variety.

Organic Phaseolus vulgaris L. seed (W. Atlee Burpee \& Co., Warminster, PN) was purchased from Home Depot, Miami, Florida. The variety, Golden Wax bush bean, produces 7.5 to $15 \mathrm{~cm}$ yellow pods ready for harvest in 54 days.

\section{Experimental Design}

The trial was carried out 18 March 2012 through 7 May 2012. The research experiment had several components, a) potted trial carried out in a greenhouse, b) soil analysis, and c) a microbial respiration study. Both (b) and (c) were carried out in a laboratory setting using soil collected from the greenhouse experiment.

\section{a) Greenhouse Trials}

Growing pots were one-gallon volume, $15 \mathrm{~cm}$ width by $20 \mathrm{~cm}$ height. A circular piece of paper towel lined the bottom of each pot to minimize soil loss. The experimental setup featured three biochar level arranged in a completely randomized design. Each treatment, a) control, b) 2\% biochar addition, c) $5 \%$ biochar addition, contained eight replicates. Seeds were germinated in trays with $6 \mathrm{~cm}$ by $3 \mathrm{~cm}$ liners; two seeds were 
planted in each hole. Soil for started seeds matched soil treatments; control soil was used for control seeds, $2 \%$ biochar treated soil was used to start seedlings for the $2 \%$ treatment pots, $5 \%$ biochar treated soil was used to start seedlings for the $5 \%$ treatment pots.

Once seedlings emerged and had true leaves, eight plants from each treatment were selected for transplant based on similar height. All were transplanted on the same day.

b) Soil Analyses

Soil cores $(1.5 \mathrm{~cm}$ in diameter, $15 \mathrm{~cm}$ depth) from the greenhouse experiment were collected in Fisher Scientific soil sample bags for elemental analysis at initial planting and at final harvest from six random pots in each treatment. Soil was also evaluated using NRCS qualitative soil health score cards. Water retention and saturation were measured using ceramic porous plates using six replicates for each treatment.

\section{c) Microbial gas flux}

Soil cores $(1.5 \mathrm{~cm}$ in diameter, $15 \mathrm{~cm}$ depth) were collected for the microbial respiration study in Fisher Scientific soil sample bags at initial planting, twice throughout the growing period (9 and 27 April 2012), and at final harvest from six random pots in each treatment in the greenhouse experiment to compare $\mathrm{CO}_{2}$ flux changes over time.

\section{Biochar Analysis}

Pulverized biochar samples were sent in triplicate to Hazen Research, Inc. (Golden, Colorado) for proximate and ultimate analysis. Analysis gave C, fixed C, N, S, H, ash, volatile matter, as well as, moisture content. Triplicate results were averaged. 


\section{Soil Analysis}

Soil quality was evaluated on the basis of soil nutrient content prior to planting, known as $\left(t_{\varnothing}\right)$ and after harvest, $\left(t_{f}\right)$.

\section{Mehlich III Extraction}

Mehlich III extraction of soil was conducted for simultaneous extraction of calcium $(\mathrm{Ca})$, potassium $(\mathrm{K})$, magnesium $(\mathrm{Mg})$, sodium $(\mathrm{Na})$, iron $(\mathrm{Fe})$, zinc $(\mathrm{Zn})$, copper (Cu), and manganese (Mn). Mehlich III was developed by Mehlich (1984) as a multielement soil extraction (Elrashidi et al., 2003). It requires several reagents, but the ability to perform an analysis for various elements using one extractant solution saves both time and money. Acetic acid $\left(\mathrm{CH}_{3} \mathrm{COOH}\right)$ prevents calcium from being precipitated as calcium fluoride; ammonium nitrate $\left(\mathrm{NH}_{4} \mathrm{NO}_{3}\right)$ facilitates the extraction of cations; nitric acid $\left(\mathrm{HNO}_{3}\right)$ is used to extract some calcium phosphates and extract micronutrient cations; ammonium fluoride $\left(\mathrm{NH}_{4} \mathrm{~F}\right)$ is used to extract iron and aluminum phosphates; ethylenediaminetetraacetic acid (EDTA) prevents precipitation of calcium fluoride and chelates micronutrients, such as copper (North Carolina Agronomy Board). This method was selected after consulting a local soil testing laboratory, A \& L Laboratory, Florida. Mehlich III is often used, but has some limitations when used in calcareous soil analysis. Phosphorus determined by Mehlich III in calcareous soil is unreliable.

\section{Mehlich III Procedure}

To prepare one liter of the extractant, approximately $200 \mathrm{~mL}$ of RO water was added to a $1 \mathrm{~L}$ volumetric flask. Using a scale, $0.556 \mathrm{~g}$ of $0.015 \mathrm{~N} \mathrm{NH}_{4} \mathrm{~F}$ was weighed and placed 
in the volumetric flask along with $0.292 \mathrm{~g}$ of $0.001 \mathrm{M}$ EDTA. The contents were stirred until dissolution. In a separate beaker, $20.010 \mathrm{~g} 0.25 \mathrm{~N} \mathrm{NH}_{4} \mathrm{NO}_{3}$ was mixed with $200 \mathrm{~mL}$ of $\mathrm{RO}$ and then added to the $1 \mathrm{~L}$ volumetric flask containing $\mathrm{NH}_{4} \mathrm{~F}-\mathrm{EDTA}$. An additional $400 \mathrm{~mL}$ of $\mathrm{RO}$ water was stirred in prior to mixing in $12.008 \mathrm{~mL}$ of $0.2 \mathrm{~N}$ $\mathrm{CH}_{3} \mathrm{COOH}$ and $0.819 \mathrm{~mL}$ of $0.013 \mathrm{~N} \mathrm{HNO}_{3}$. Using $\mathrm{RO}$ water, the extractant was brought to the $1 \mathrm{~L}$ mark and thoroughly mixed.

Soil samples were sieved to $<2 \mathrm{~mm}$ and $2.0 \mathrm{~g}$ of soil was weighed into a 25 $\mathrm{mL}$ centrifuge tube. Using a pipette, $20 \mathrm{~mL}$ of Mehlich III extracting solution was added. Samples were transferred to a shaker for $5 \mathrm{~min}$ at 200 oscillations per minute at room temperature. Samples were removed from the shaker and centrifuged at $2000 \mathrm{rpm}$ for 8 minutes. Solutions were filtered using Whatman \#1 filter paper and stored in glass scintillation vials in a refrigerator at $4{ }^{\circ} \mathrm{C}$ until analysis could be performed. Corresponding soil samples were also weighed in aluminum trays and oven dried at $80^{\circ} \mathrm{C}$ to approximate an air dry fraction.

Multi-element analysis of extracted soil was conducted using inductively coupled plasma-atomic emission spectrometry (ICP-AES) at the USDA ARS, Miami, Florida. This procedure allowed for simultaneous determination of $\mathrm{Ca}, \mathrm{Cu}, \mathrm{Fe}$, K, Na, Mg, Mn, P, and Zn.

\section{Olsen Extraction}

Available Phosphorus (P) was determined using Olsen's sodium bicarbonate method (Olsen et al. 1954.) The Olsen extractant is $0.5 \mathrm{M}$ sodium bicarbonate $\left(\mathrm{NaHCO}_{3}\right)$ solution at a $\mathrm{pH}$ of 8.5 . This extractant was selected because of its 
applicability to alkaline and calcareous soils (Elradashi 2008; Buurman et al., 1996). This extractant decreases calcium in the solution through the precipitation of $\mathrm{Ca}^{2+}$ as $\mathrm{CaCO}_{3}$, which in turn increases the solubility of Ca-phosphates (IFAS; Soil and Plant Analysis Council, 1999).

\section{Olsen Procedure}

To prepare the extractant, $42 \mathrm{~g}$ of $0.5 \mathrm{M} \mathrm{NaHCO}_{3}$ was weighed and placed in a 1 liter volumetric flask with $990 \mathrm{~mL}$ of distilled deionized water (DDI). The solution was stirred using a magnetic stirring plate until completely dissolved. The $\mathrm{pH}$ was tested using an electrode $\mathrm{pH}$ meter. To raise the $\mathrm{pH}$ to $8.5,1 \mathrm{M} \mathrm{NaOH}$ (sodium hydroxide) was added drop by drop until $\mathrm{pH}$ stabilized at 8.5. Distilled deionized water was added to the volumetric flask to reach1 $\mathrm{L}$ and stirred.

Soil samples were sieved to $<2 \mathrm{~mm}$ and $1.0 \mathrm{~g}$ of soil was weighed into a $25 \mathrm{~mL}$ centrifuge tube. Using a pipette, $20 \mathrm{~mL}$ of the $\mathrm{NaHCO}_{3}$ extracting solution was added and tubes were tightly capped. Samples were placed for 30 minutes on a platform shaker at 200 oscillations per minute for 30 minutes. Samples were removed from the shaker and centrifuged at $2000 \mathrm{rpm}$ for 10 minutes. The solution was filtered into flasks through Whatman \#42 filter paper and stored in small scintillation vials and refrigerated at $4{ }^{\circ} \mathrm{C}$ until analysis could be performed. Corresponding soil samples were also weighed in aluminum trays and oven dried at $80^{\circ} \mathrm{C}$ to approximate air dry fraction.

$T C / T N$

Total nitrogen (TN) and total carbon (TC) for all treatments was determined using a CHN 628 combustion analyzer (LECO Corp, MI) and a method by Jackson (1967). 
Soil samples were oven dried at $80{ }^{\circ} \mathrm{C}$ and pulverized. Approximately $0.2500 .040 \mathrm{mg}$ of soil were weighed to into aluminum foil wraps for analysis with $20 \%$ replication.

\section{Plant Growth}

Plant height, shoot biomass weight, pod weight, average pod length, leaf area, specific leaf area, and root-shoot ratio were measured using methods adapted from Wood and Roper (2000). Chlorophyll content in leaves was measured using a SPAD502, Japan, three times throughout the growing process using an average of thirty leaves. Plant height was measured bi-weekly from the first cotyledon as a reference point to the highest leaf node. At harvest shoot, root, as well as separated pods and leaves were all immediately weighed. Roots were carefully removed and then washed to remove soil, which was collected for additional analysis and experimentation. Roots were then scanned at the USDA ARS, Miami, Florida.

Shoots and roots were then oven dried at $45^{\circ} \mathrm{C}$ until there was no weight change with additional drying and oven dry weights were recorded.

\section{Microbial Gas Flux}

Microbial respiration of $\mathrm{CO}_{2}$ was measured with gas chromatography in three week intervals from the beginning of the experiment until harvest time using a method adapted from Amador and Jones (1993) using Hewlett Packard (HP) 5890 Series II Gas Chromatograph equipped with a Flame Ionization Detector and a Shimadzu MTN-1 Methanizer and a HySep R 80/100 Column. The Headspace sampler was a HP 7694 and software, E-Lab. 
Approximately $3.5 \mathrm{~g}$ to $4.5 \mathrm{~g}$ of each soil sample was weighed into small plastic retention cups and an equal volume of DDI was added to create a 1:1 soil to water slurry. Between $4.00 \mathrm{~g}-5.50 \mathrm{~g}$ of the soil slurry was pipetted into labeled glass scintillation vials. Vials were capped with rubber stoppers and aluminum seals. Samples were purged with $\mathrm{CO}_{2}$ free air. Samples were incubated for 3 days $(\sim 72$ hours). Standard vials were purged with $\mathrm{CO}_{2}$ free air and prepared using gas syringes and a $\mathrm{CO}_{2}$ tank. Samples were placed in the headspace sampler and processed.

\section{Statistics}

Using SPSS, Inc. V.18 and V.21, (Chicago, Illinois), all variables were checked for normality of variance prior to conducting further analysis. Logarithmic transformations were not necessary. One-way between groups analysis of variance (ANOVA) was conducted on all variables to explore the impact of biochar (BC) application on plant growth, soil quality, and microbial gas flux (in the form of $\mathrm{CO}_{2}$ emission). Plants and soil were divided into three equal treatment groups (Control group, 2\% BC group, and 5\% BC group). When a statistically significant difference was found at the $\mathrm{p}<0.05$ level or less, Post-hoc comparisons using the Tukey-HSD test were performed. 


\section{RESULTS}

\section{Biochar Analysis}

Analysis of M. quinquenervia biochar produced through lo-oxic conditions at $350^{\circ} \mathrm{C}$ was conducted through Hazen Research, Inc., Golden, Colorado. Three $20 \mathrm{~g}$ biochar samples were analyzed.

Table 1. Elemental composition of Melaleuca quinquenervia biochar produced at pyrolysis temperature of $350{ }^{\circ} \mathrm{C}$. Presented are triplicate means $\pm \mathrm{SD}$ of samples $(\mathrm{n}=3)$.

\begin{tabular}{|l|rl|}
\hline $\begin{array}{c}\text { Elemental } \\
\text { Composition }\end{array}$ & \multicolumn{2}{|c|}{$\% \pm$ SD } \\
\hline Carbon & 84.20 & \pm 0.84 \\
Hydrogen & 3.28 & \pm 0.13 \\
Nitrogen & 0.37 & \pm 0.03 \\
Sulfur & 0.02 & \pm 0.02 \\
Ash & 1.68 & \pm 0.06 \\
Oxygen & 10.45 & \pm 0.71 \\
\hline
\end{tabular}

\section{Seed Germination}

Germination of Phaseolus vulgaris L. seeds was highest in the 5\% biochar treated soil. An equal number of individual seeds were planted in small trays and kept at the same temperature and lighting. Out of thirty seeds planted, twenty one sprouted within ten days from the $5 \% \mathrm{BC}$ treated soil, sixteen sprouted within ten days in the control soil, and eighteen seeds sprouted within twelve days in the $2 \% \mathrm{BC}$ treated soil. After the twelfth day, no more seeds sprouted. The control soil only had successful germination of $53 \%$, while the $5 \%$ biochar treated soil had a germination of $70 \%$ (Fig. 2). 
Figure 2. Germination of Phaseolus vulgaris $L$ seeds for control, $2 \%$ and $5 \%$ biochar treatment groups.

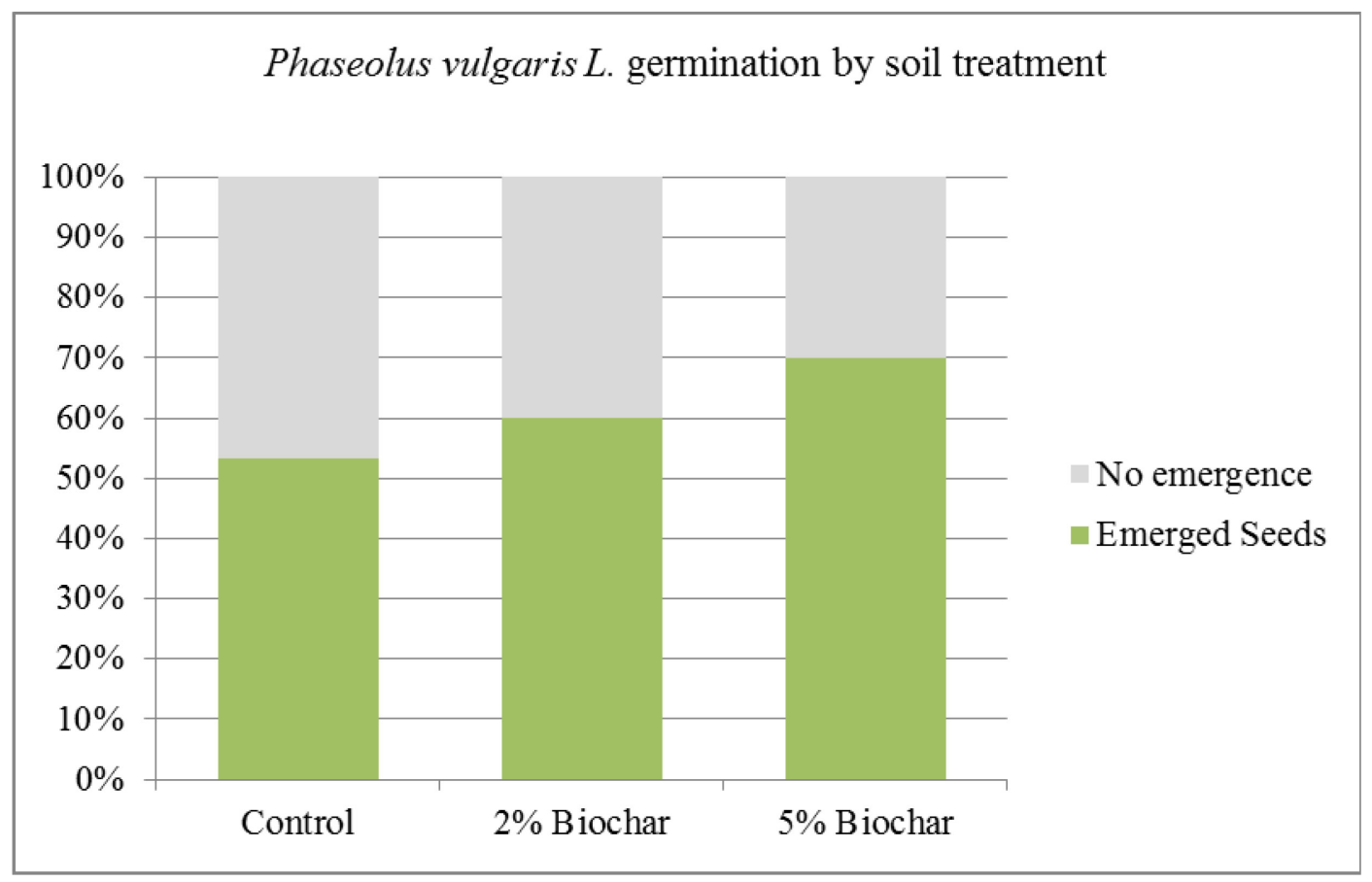

\section{Plant Growth}

The experiment began with eight replicates in each treatment group. Plant mortality was equally high across all treatments; only four plants per treatment group remained at harvest time. Overall, Phaseolus vulgaris L. plants grown in control soil were healthiest in terms of shoot weight, fruit production, plant height, and leaf area. Total production of above ground biomass far exceeded both the $2 \%$ biochar and $5 \%$ biochar soil treatments. A one-way between groups analysis of variance was performed. There was a statistically significant difference in above ground biomass at $\mathrm{p}<0.001$ for the three treatment groups: F $(2,9)=28.88$. Post-hoc comparison using the TukeyHSD test indicated the mean $\pm \mathrm{SD}$ for the Control group $(\mathrm{M}=8.21 \pm 0.55)$ was significantly larger than the $2 \%$ 
BC group $(M=4.24 \pm 1.12)$ and $5 \%$ BC group $(M=4.09 \pm 0.85)$. The $2 \%$ and $5 \%$ treatment groups did not differ (Fig.3).

Figure 3. Above ground Phaseolus vulgaris L.biomass (shoot) means for all treatments; dry weight $(\mathrm{g})$.

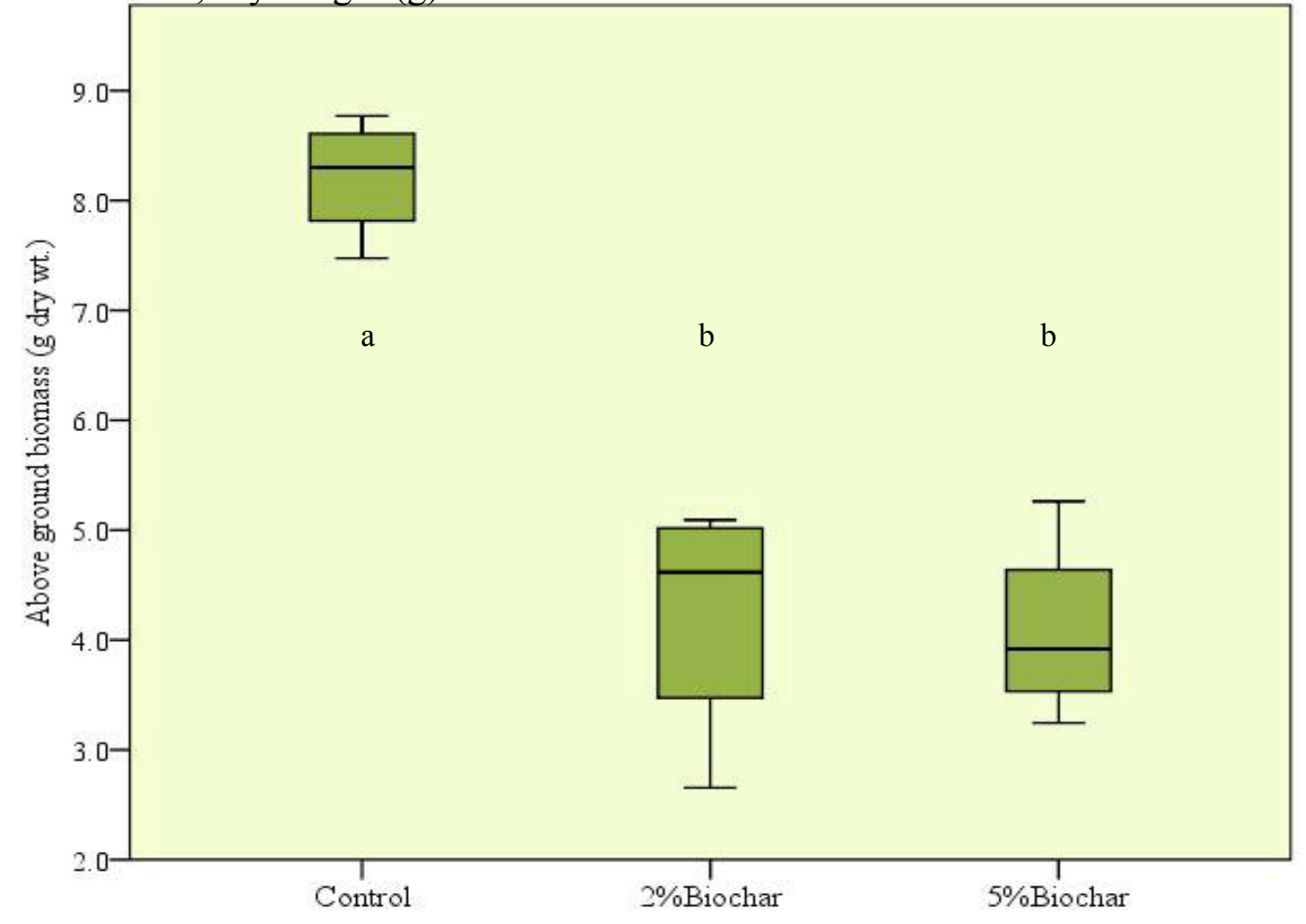

A one-way, between groups analysis of variance was also conducted to explore the impact of biochar application on total fruit production at harvest using pod weight (g). There was a statistically significant difference in pod weight for the three treatment groups: $F(2,9)=60.48, p<0.001$. Post-hoc comparisons using the Tukey-HSD test indicated that the mean $\pm \mathrm{SD}$ for the Control group $(\mathrm{M}=4.25 \pm 0.66)$ was significantly larger than the $2 \%(\mathrm{M}=0.78 \pm 0.47)$ and $5 \%(\mathrm{M}=0.54 \pm 0.45)$. The $2 \%$ and $5 \%$ treatments did not differ (Fig. 4 ). 
Figure 4. Phaseolus vulgaris $\mathrm{L}$. fruit production for all treatment groups, measured as pod dry weight (g).

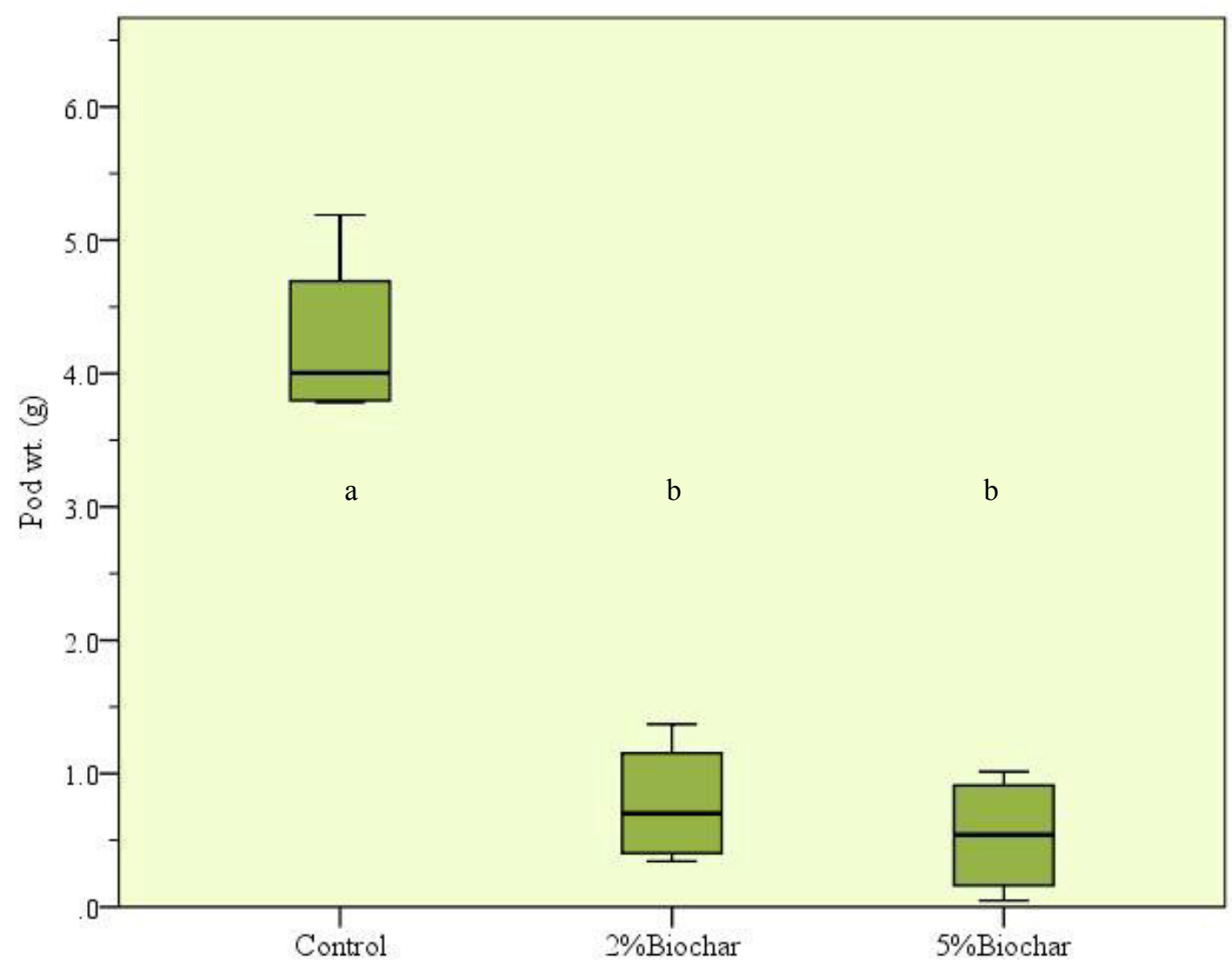

The quantity of pods produced varied greatly within and between treatments. On average, healthy plants produced six to nine pods. One plant in the $2 \% \mathrm{BC}$ group produced twenty two pods, but none grew to full size; See Image 4 and Table 3. Pod count proved useless as measure of fruit production because several unhealthy plants were still producing immature pods. Mean pod length $(\mathrm{mm})$ for each treatment was calculated using the length of all pods in each group divided by the overall quantity of pods measured (Fig. 5). There was a statistically significant difference between the 
control group and both biochar treatment groups: $\mathrm{F}(2,9)=23.57, \mathrm{p}<0.001$; Post-hoc, Tukey-HSD - Control group $(M=110.81 \pm 10.22)$ was significantly larger than the $2 \%$ BC group $(M=48.90 \pm 9.23)$ and $5 \% B C$ group $(M=53.31 \pm 20.44)$.

Figure 5. Mean pod length (mm) from Phaseolus vulgaris L. plants at harvest for Control, $2 \%$ and $5 \%$ biochar treatment groups.

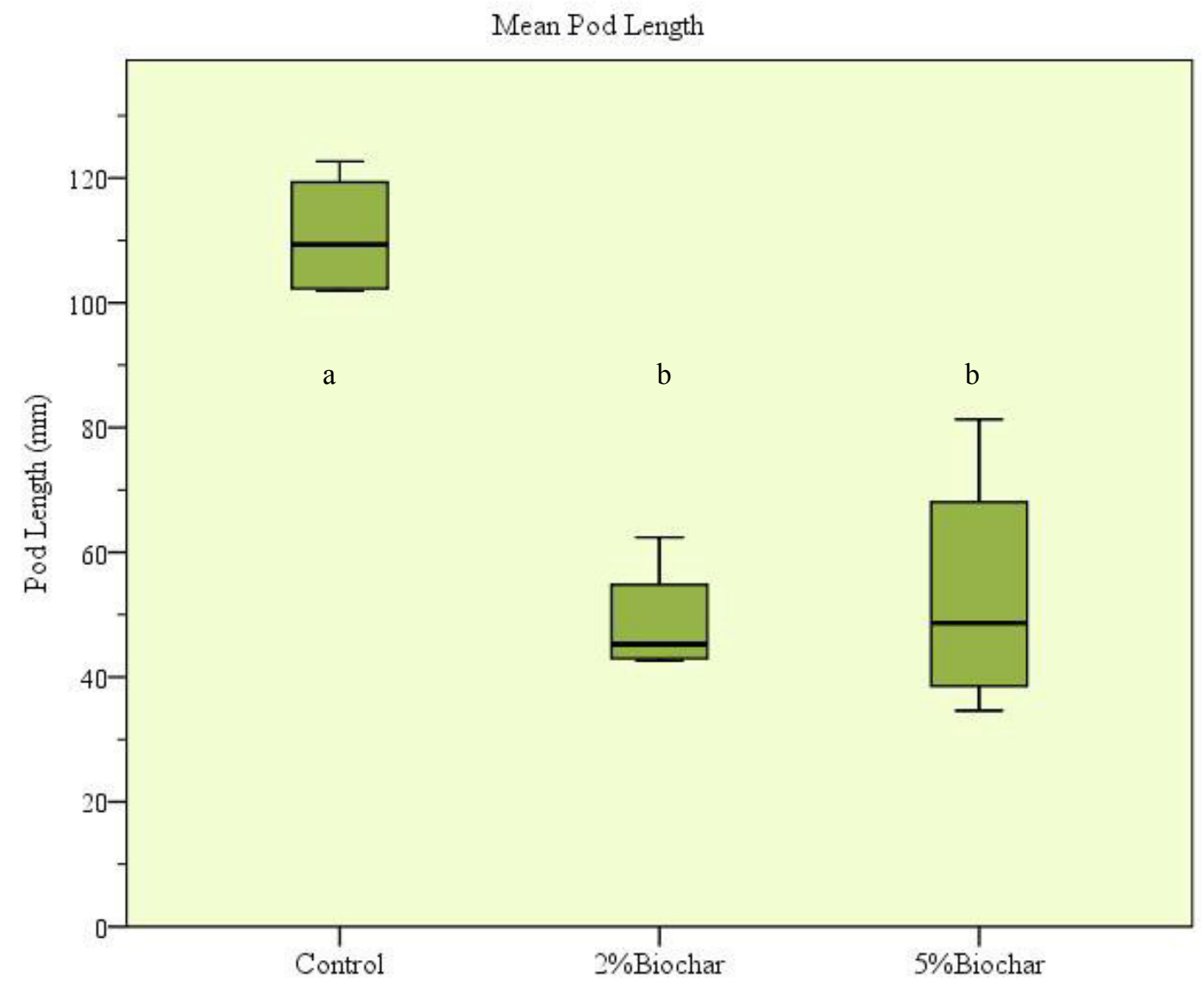


Figure 6. Side by side comparison of above ground biomass from a control plant and $2 \% \mathrm{BC}$ treated plant.

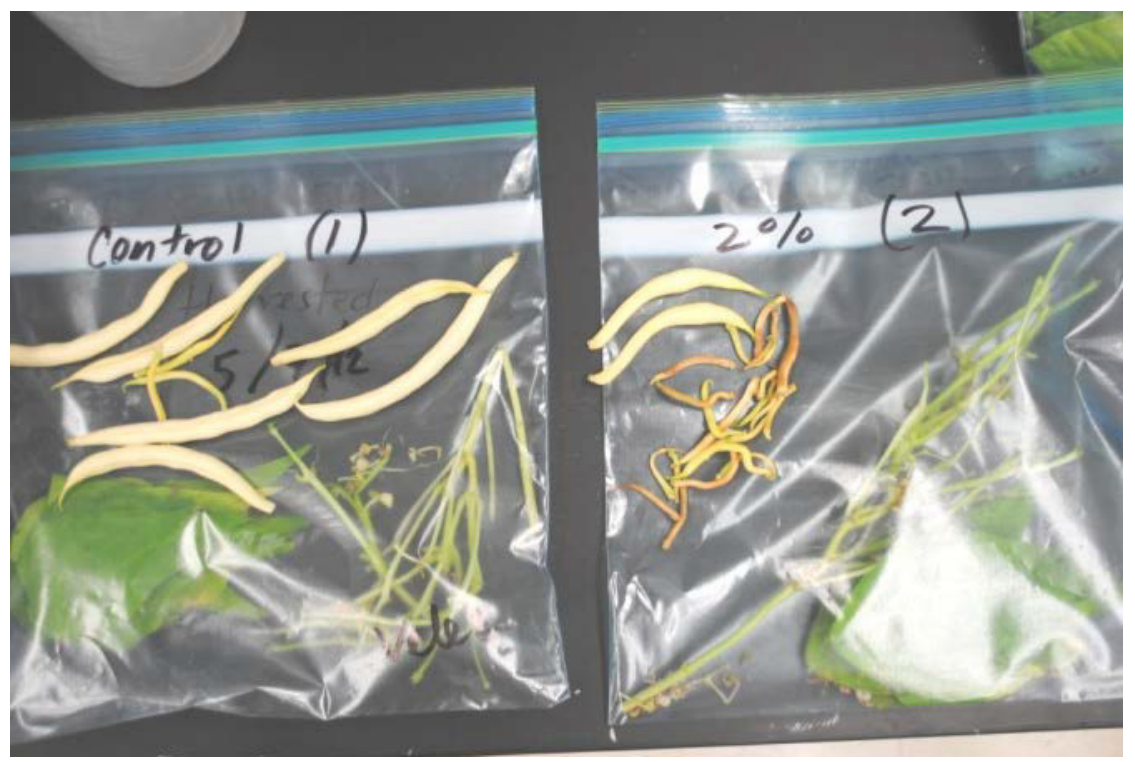

Table 2. Pod count and dry weight (g) for all plants.

\begin{tabular}{cccc}
\hline \hline Treatment & Pot \# & $\begin{array}{c}\text { Number of } \\
\text { Pods }\end{array}$ & $\begin{array}{c}\text { Pod Dry Weight } \\
(\mathrm{g})\end{array}$ \\
\hline Control & 1 & 9 & 5.1883 \\
Control & 4 & 9 & 3.7866 \\
Control & 6 & 7 & 3.8092 \\
Control & 7 & 6 & 4.1982 \\
\hline & & & \\
$2 \% \mathrm{BC}$ & 2 & 22 & 1.3707 \\
$2 \% \mathrm{BC}$ & 4 & 10 & 0.9359 \\
$2 \% \mathrm{BC}$ & 5 & 6 & 0.4651 \\
$2 \% \mathrm{BC}$ & 6 & 8 & 0.3421 \\
\hline & & & \\
$5 \% \mathrm{BC}$ & 2 & 8 & 0.2753 \\
$5 \% \mathrm{BC}$ & 4 & 6 & 1.0147 \\
$5 \% \mathrm{BC}$ & 6 & 5 & 0.8076 \\
$5 \% \mathrm{BC}$ & 8 & 2 & 0.0482 \\
\hline
\end{tabular}


Several plants grown in biochar treated soil displayed varying degrees of leaf stress.

Both the $2 \%$ and $5 \%$ treatments experienced wilting, thickening, discoloration, or leaf chlorosis (Fig. 7). None of the plants grown in control soil displayed similar leaf stress (Fig. 8).

Figure 7. 5\% BC treated Phaseolus vulgaris L. Note: leaf discoloration and stunted growth

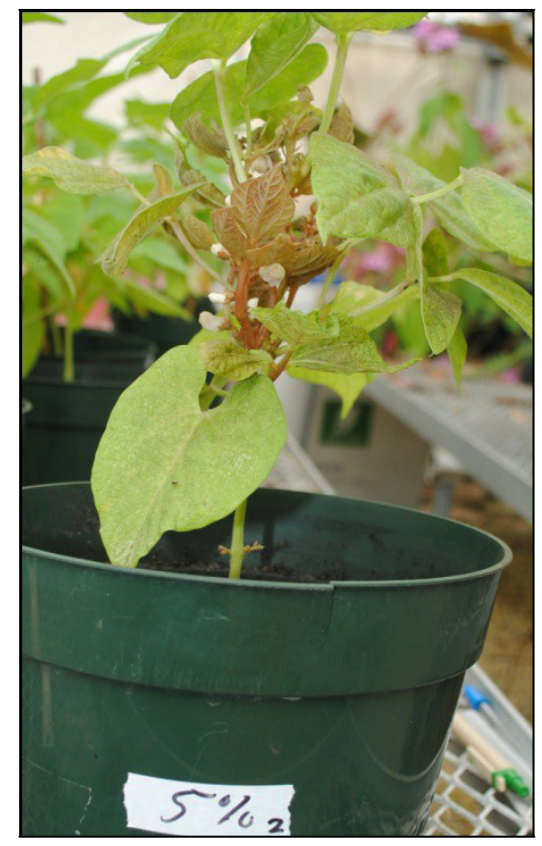

Figure 8. Phaseolus vulgaris L.

Control plant. Note: green and healthy leaves, no discoloration

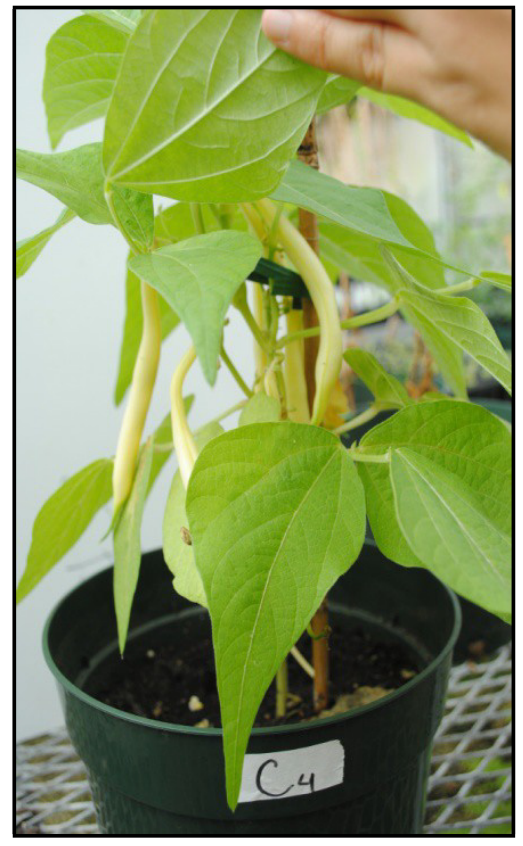

Figure $9 \mathrm{a}$ and $9 \mathrm{~b}$ show healthy plants and fruit set from the control group at harvest time. Figure $9 \mathrm{c}$ and $9 \mathrm{~d}$ are from the $2 \%$ biochar group and Figure $9 \mathrm{e}$ and $9 \mathrm{f}$ are from the $5 \%$ biochar group. The photographs show a stark contrast in pods production. Control snap beans are healthy, pale yellow and waxy. The majority of snap beans from both the $2 \% \mathrm{BC}$ and $5 \% \mathrm{BC}$ treatments were discolored, small, and dull. 
Figure $9 \mathrm{a}-\mathrm{b}$. Healthy above ground biomass harvested from two Phaseolus vulgaris L. plants in the control group.
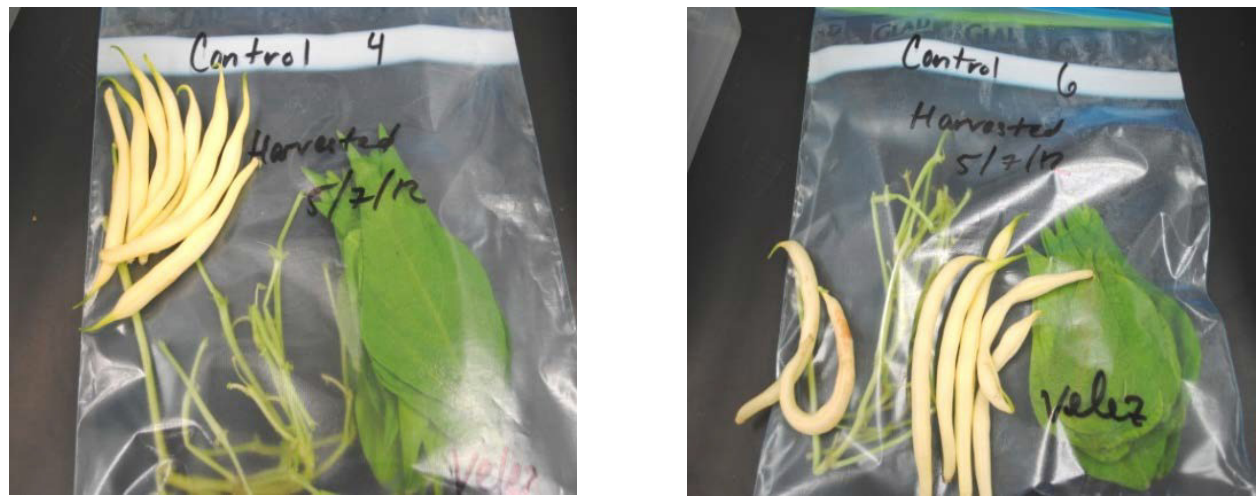

Figure $9 \mathrm{c}-\mathrm{d}$. Above ground biomass harvested from two Phaseolus vulgaris L. plants in the $2 \% \mathrm{BC}$ group; note small pod size and discoloration.
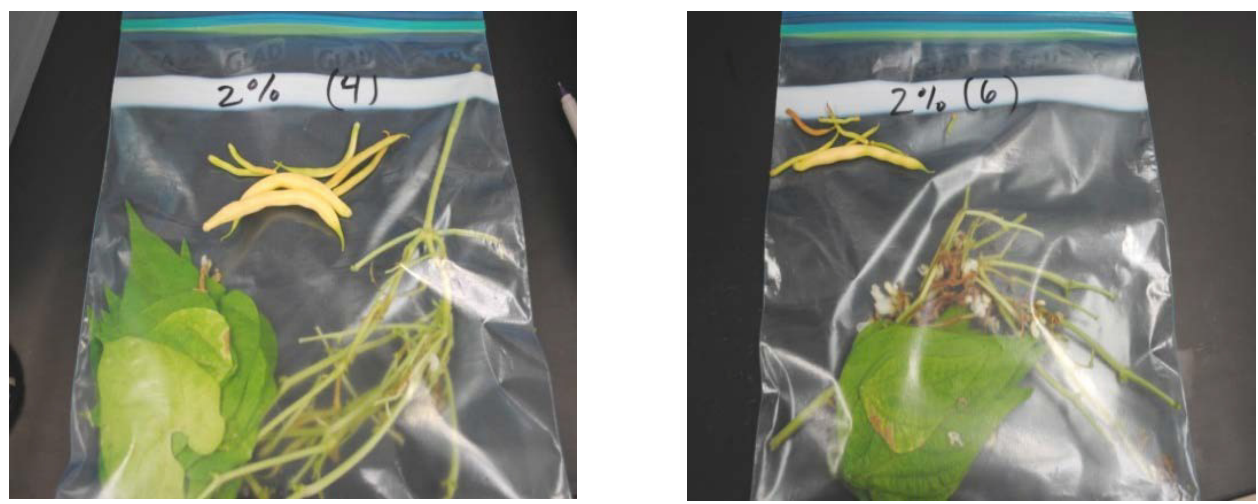

Figure 9 e - f. Above ground biomass harvested from two Phaseolus vulgaris L. plants in the 5\% BC group; note small pod size and discoloration.
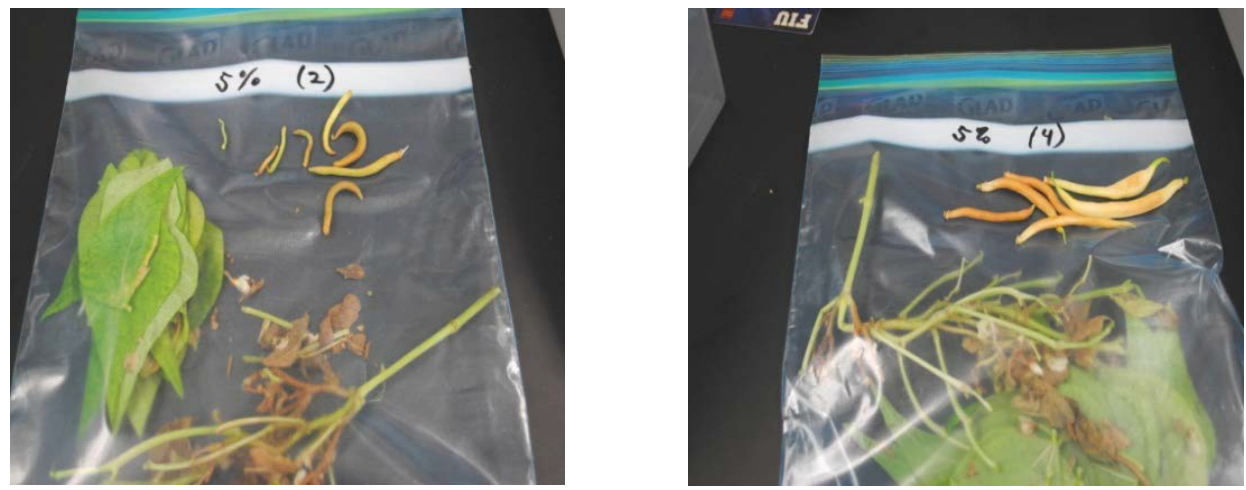
Plant height $(\mathrm{mm})$ was measured from one week after seedling transplant until harvest using the first cotyledon as a consistent base point for measurement and the highest leaf base. The control group had the overall tallest plants, but the rate of growth was similar among all treatment groups. Fig. 10 shows the mean difference in plant growth from initial transplant, $\left(\mathrm{t}_{\varnothing}\right)$ and after harvest, $\left(\mathrm{t}_{\mathrm{f}}\right)$. There was a significant difference: $F(2,9)=23.57, p<0.001$. Post-hoc, Tukey-HSD showed the Control group $(\mathrm{M}=110.81 \pm 10.22)$ was significantly larger than the $2 \% \mathrm{BC}$ group $(\mathrm{M}=48.90 \pm 9.23)$ and $5 \% \mathrm{BC}$ group $(\mathrm{M}=53.31 \pm 20.44)$. The $2 \%$ and $5 \%$ biochar groups were not different from each other.

Figure 10. Mean change in Phaseolus vulgaris $\mathrm{L}$. height $(\mathrm{mm})$ from $\left(\mathrm{t}_{\varnothing}\right)$ to $\left(\mathrm{t}_{\mathrm{f}}\right)$ for all treatment groups

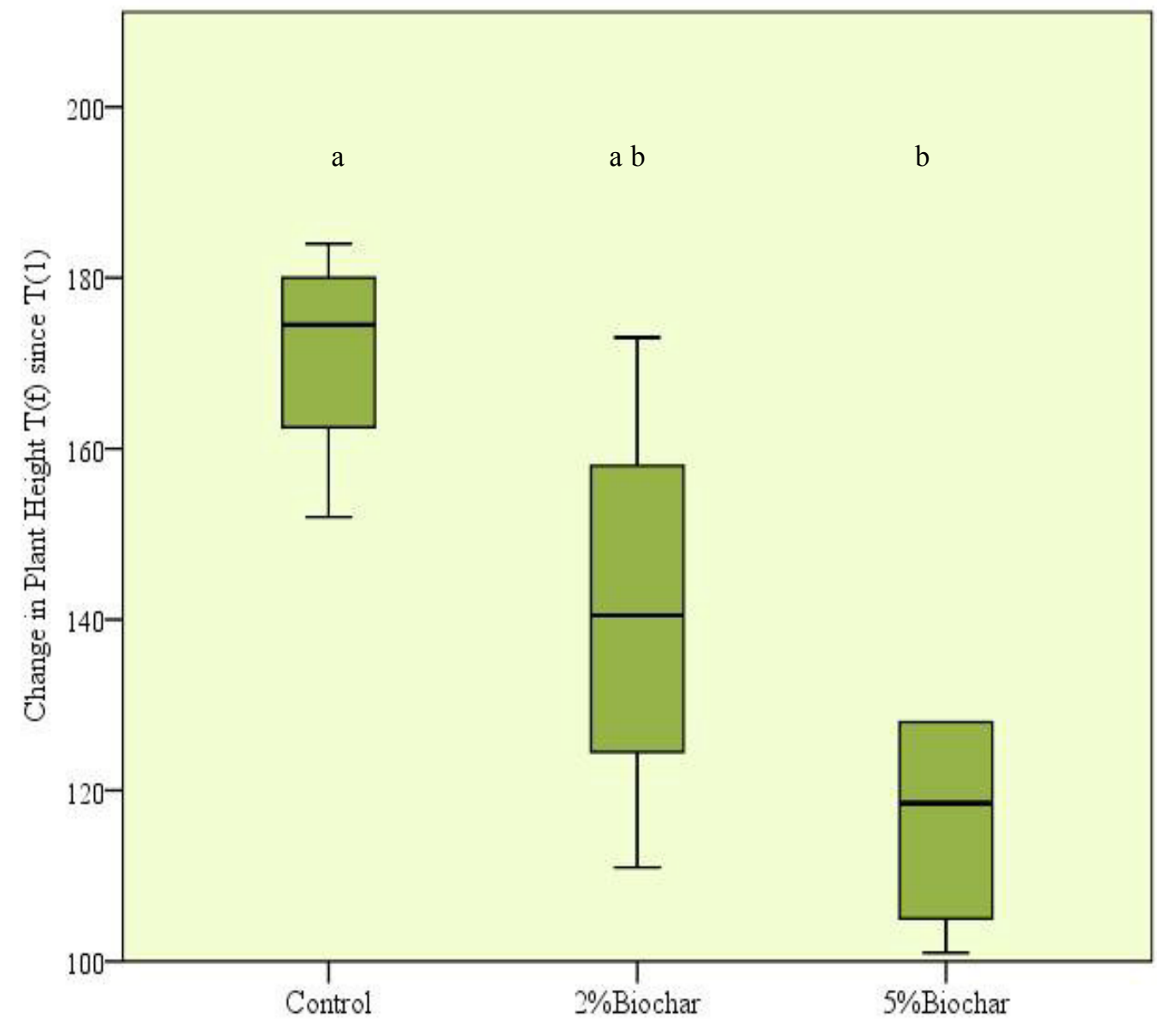


Figure 11. Phaseolus vulgaris L. growth $(\mathrm{mm})$ from $\left(\mathrm{t}_{\varnothing}\right)$ to $\left(\mathrm{t}_{\mathrm{f}}\right)$ for all treatment groups.

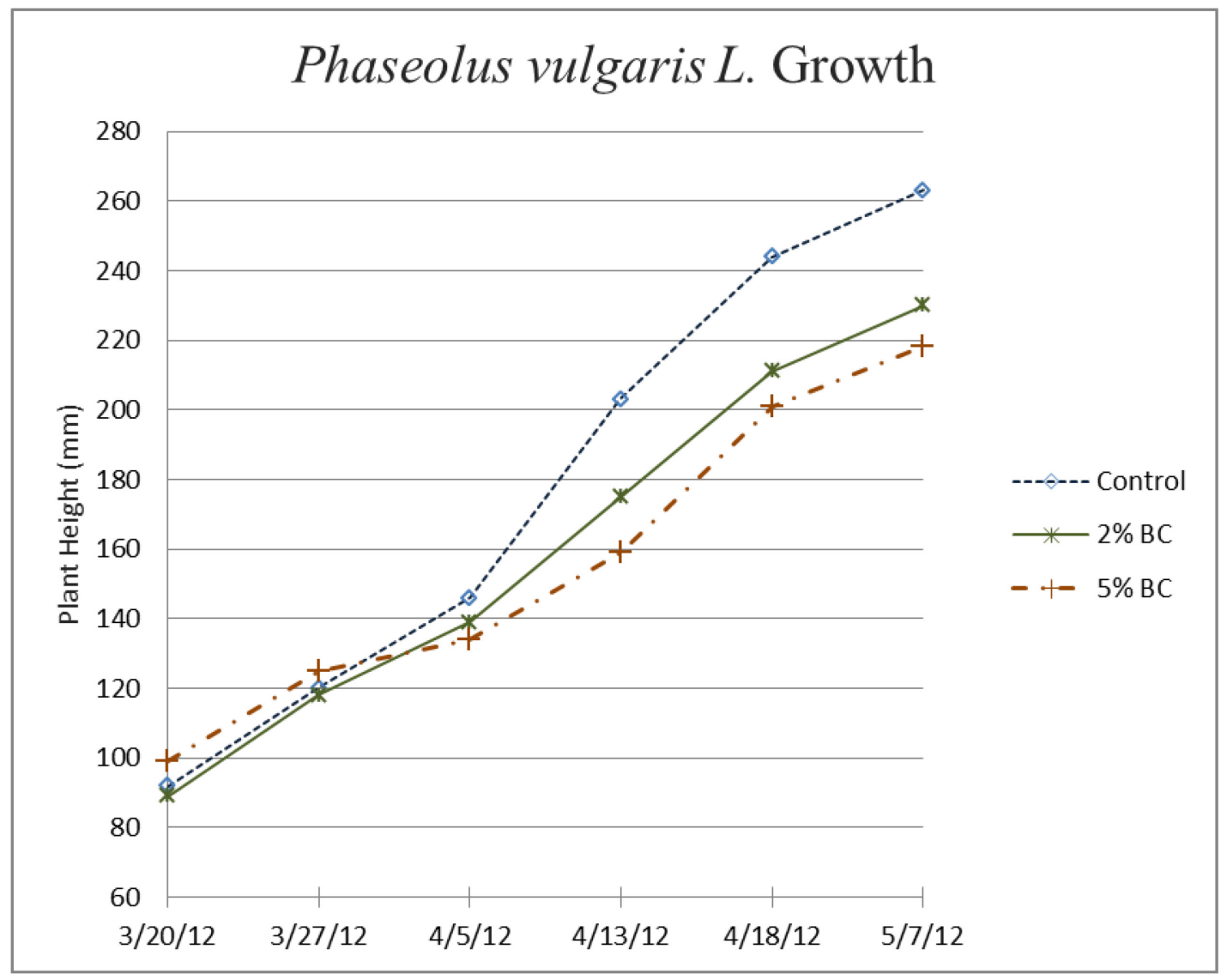

Leaf area $\left(\mathrm{cm}^{2}\right)$, specific leaf area $\left(\mathrm{cm}^{2} \mathrm{~g}-1\right)$, and root-shoot ratio were also used as measures of plant growth. Leaf area was measured immediately after plant harvest for all treatments (Fig. 11). Leaves were oven dried at $70{ }^{\circ} \mathrm{C}$ and weighed. Specific leaf area was calculated by dividing leaf area by dry leaf mass (Fig. 12). While differences were seen in the leaf area and specific leaf area, these differences were not statistically significant. Figure 3 highlights how different shoot mass was between the control group and both biochar treatments, however, when root-shoot ratio was calculated there was not much variability and no significant difference (Fig. 14). 
Figure 12. Mean Leaf Area $\left(\mathrm{cm}^{2}\right)$ of Phaseolus vulgaris L. for all treatment groups. measured with a portable leaf area meter LICOR 3100.

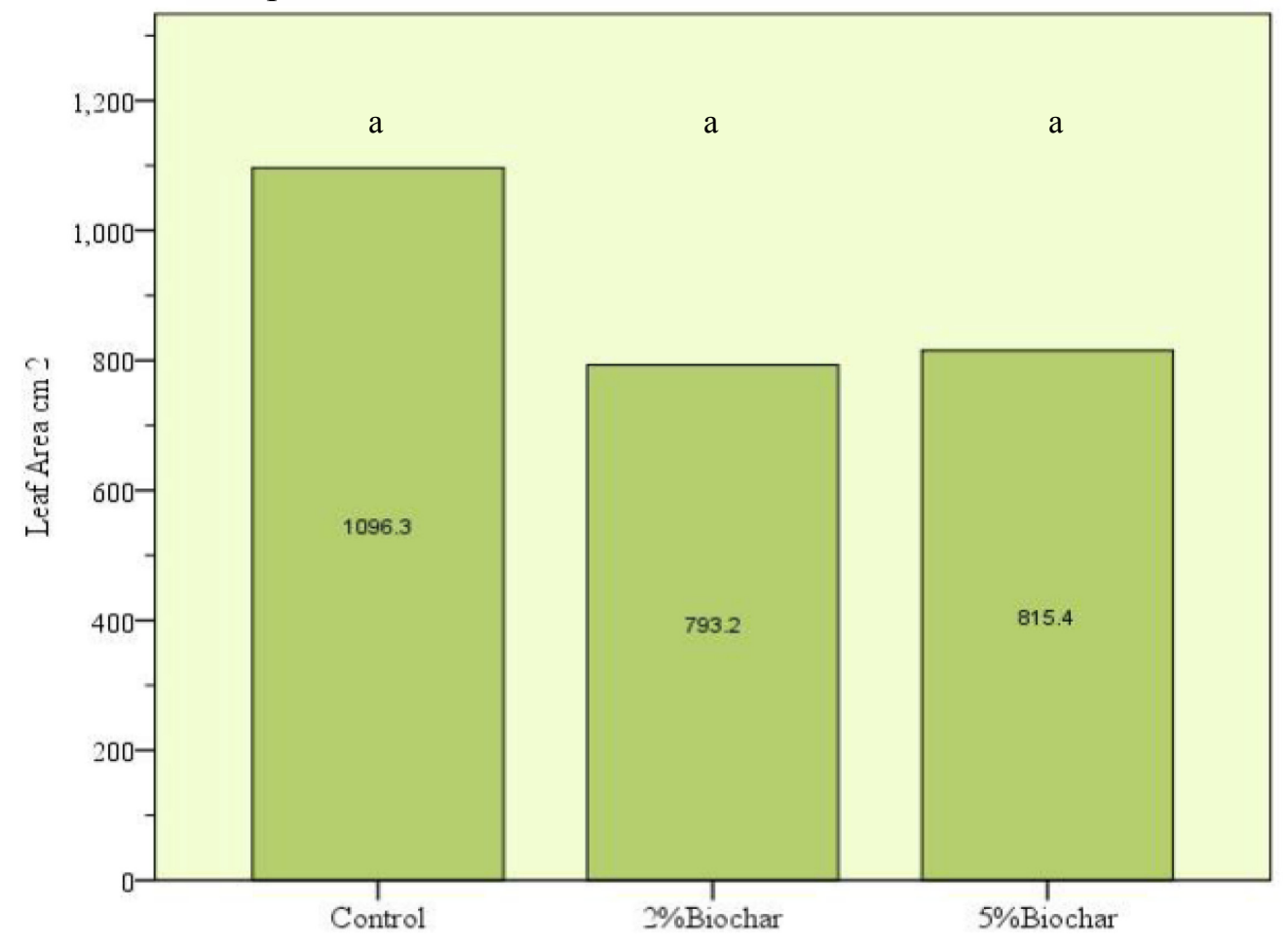

Figure 13. Phaseolus vulgaris L. Specific Leaf Area means $\left(\mathrm{cm}^{2} \mathrm{~g}^{-1}\right)$.

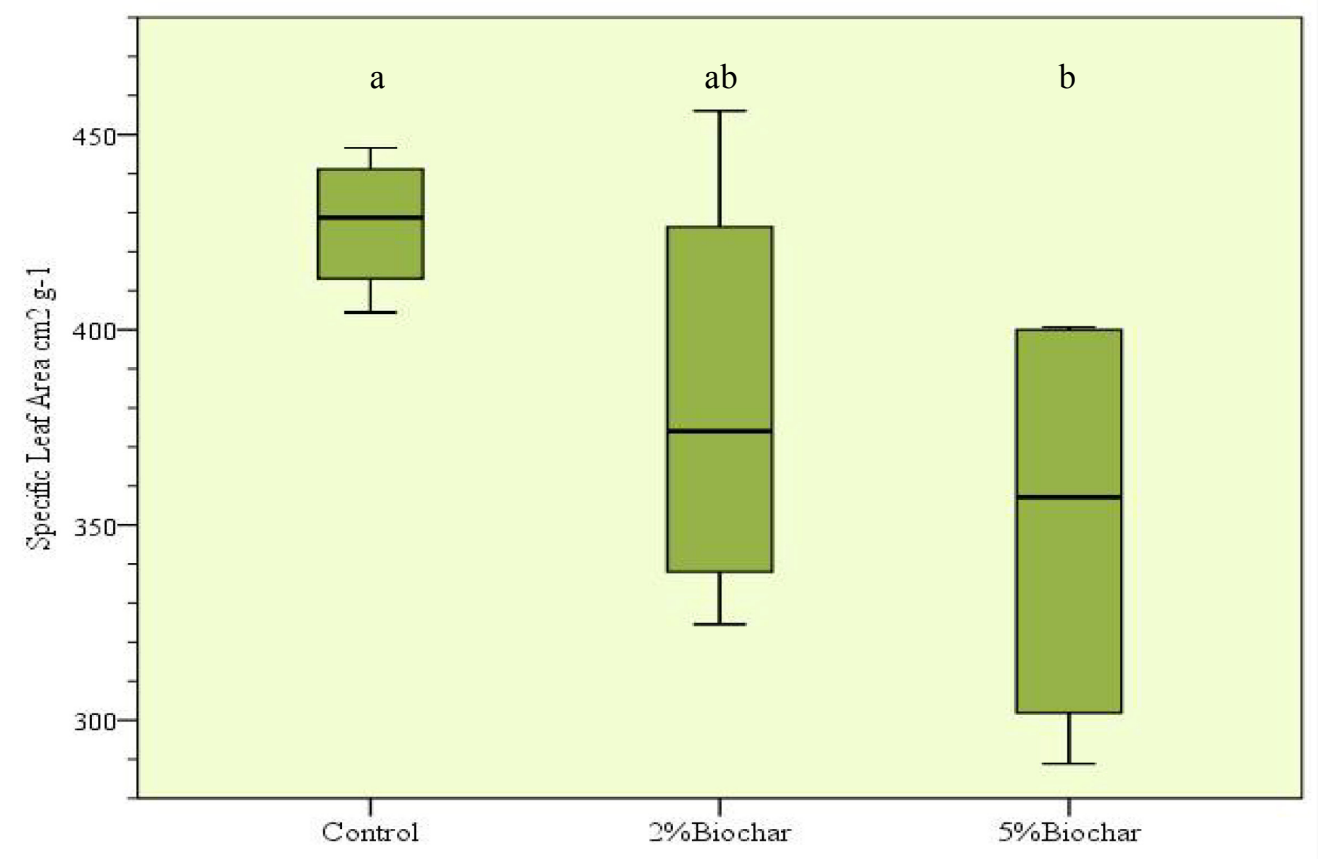


Figure 14. Phaseolus vulgaris L. Root-Shoot Ratio for Control, 2\% and 5\% biochar treatment plants.

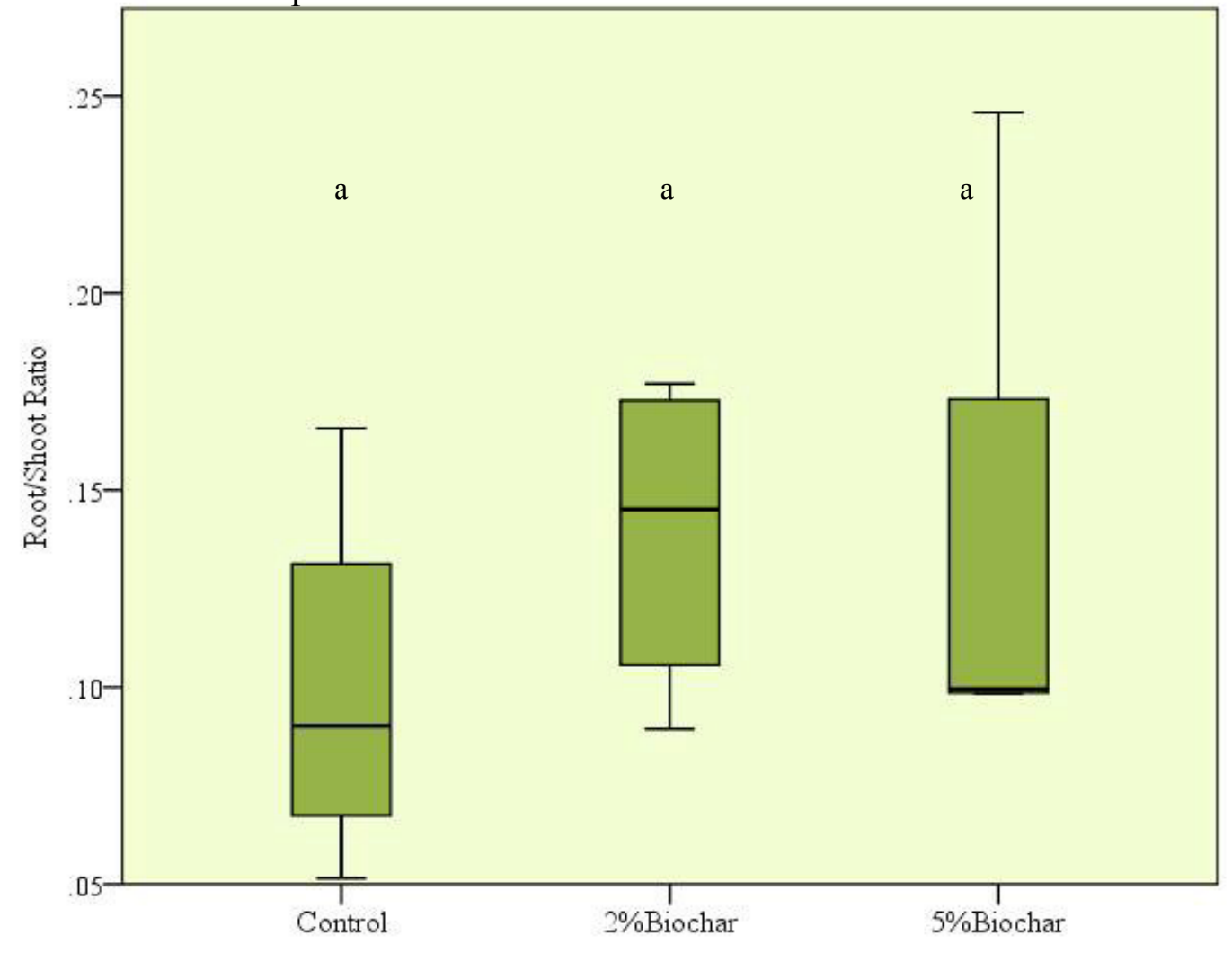

Photographic images of all plant roots were taken at harvest. The control group roots, shown in Fig. 15, are dense and short; the control roots also show abundant nodulation resulting from rhizobium bacteria symbiosis, a positive sign in nitrogen fixing bean plants. The $2 \%$ biochar plant roots (Fig. 16) are not as dense as the control groups and are longer, but nodulation is also present. The $5 \%$ roots had one dense root system and the rest were not as healthy as roots from the other two groups, however, nodulation is also present in at least two of the root systems(Fig. 17). 
Figure 15. Phaseolus vulgaris L. plant roots for the Control group

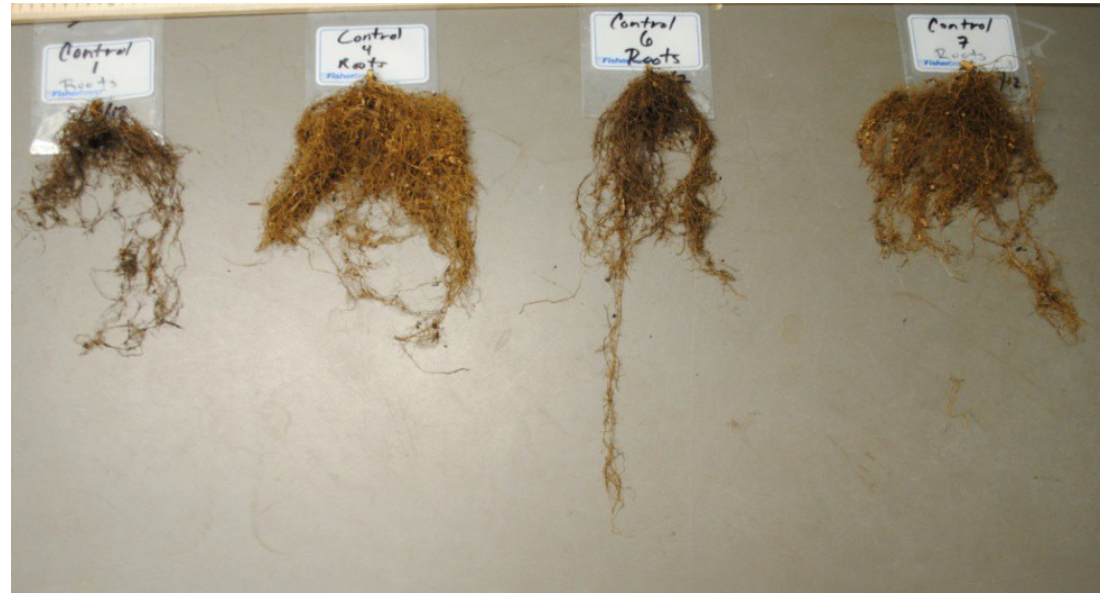

Figure 16. Phaseolus vulgaris $\mathrm{L}$. plant roots for $2 \% \mathrm{BC}$ treatment group

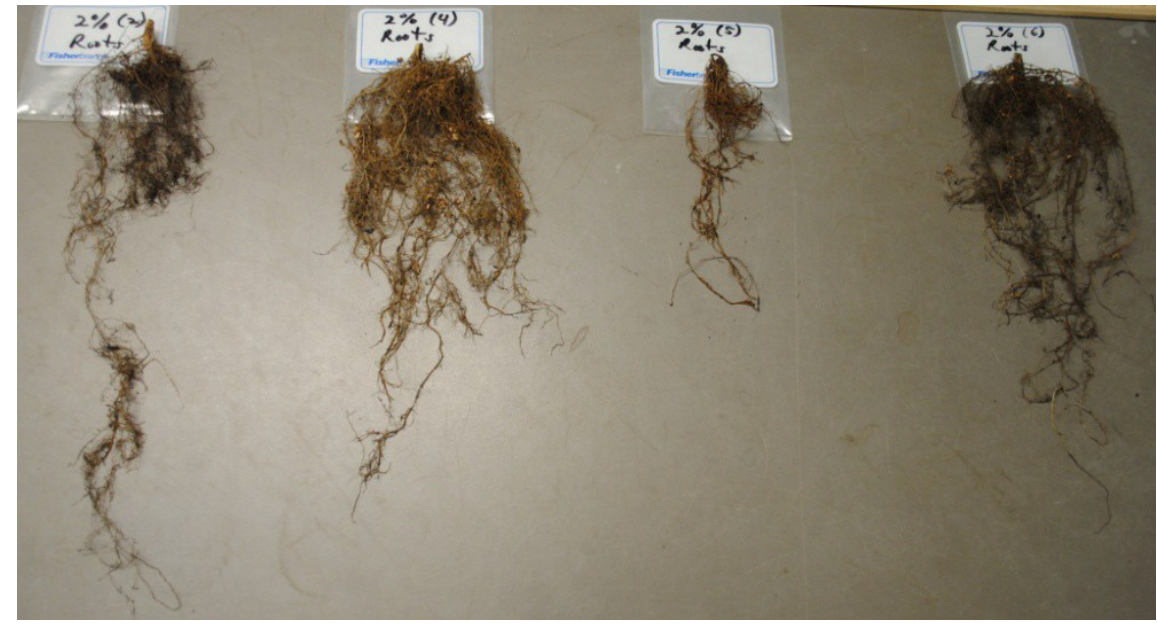

Figure 17. Phaseolus vulgaris L. plant roots for the 5\% BC treatment group.

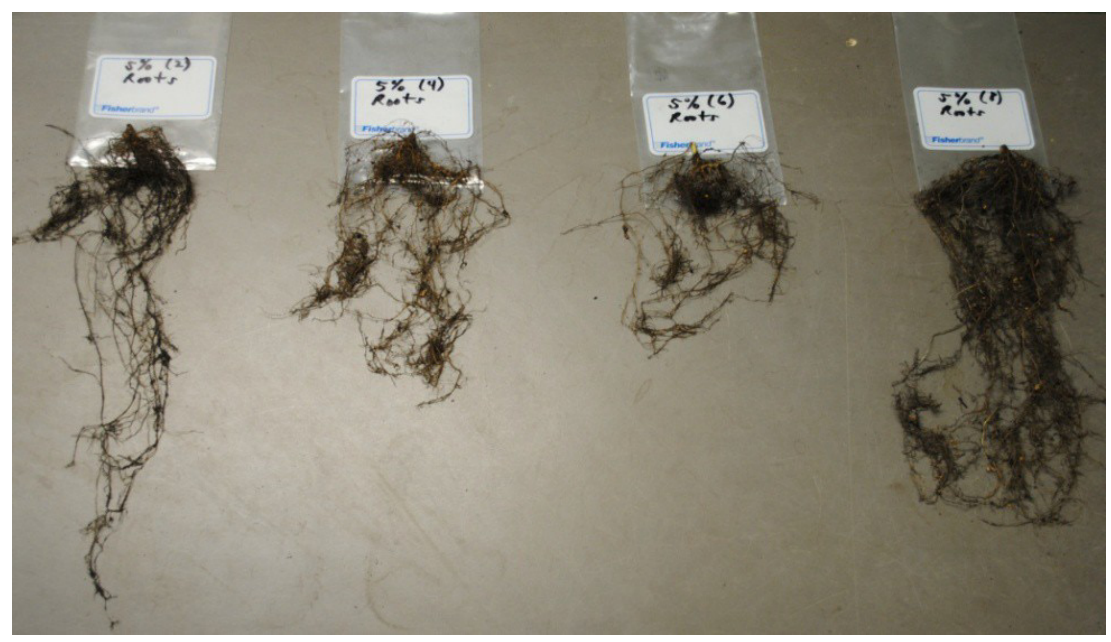




\section{Microbial Gas Flux}

Microbial respiration, in terms of carbon dioxide emission, was calculated using soil samples from the green house experiment. Soil samples were incubated on March 19, 2012 prior to planting, $\left(t_{\varnothing}\right)$. The second set of soil samples, $\left(t_{1}\right)$, incubated April 9, 2012, showed a decrease in $\mathrm{CO}_{2}$ flux from biochar treated soils. At $\left(\mathrm{t}_{2}\right)$, April 27, 2012, the decrease in $\mathrm{CO}_{2}$ is still evident. The soil from harvest, $\left(\mathrm{t}_{\mathrm{f}}\right)$, was used as a final measure. At $t_{f}$, the carbon dioxide emitted is almost equal between the control and treatment groups. Figure 10 charts carbon dioxide production over time.

Figure 18. $\mathrm{CO}_{2}$ production means from Control, $2 \%$ and $5 \% \mathrm{BC}$ treatment groups from $\left(t_{\varnothing}\right)$ through $\left(t_{f}\right)$.

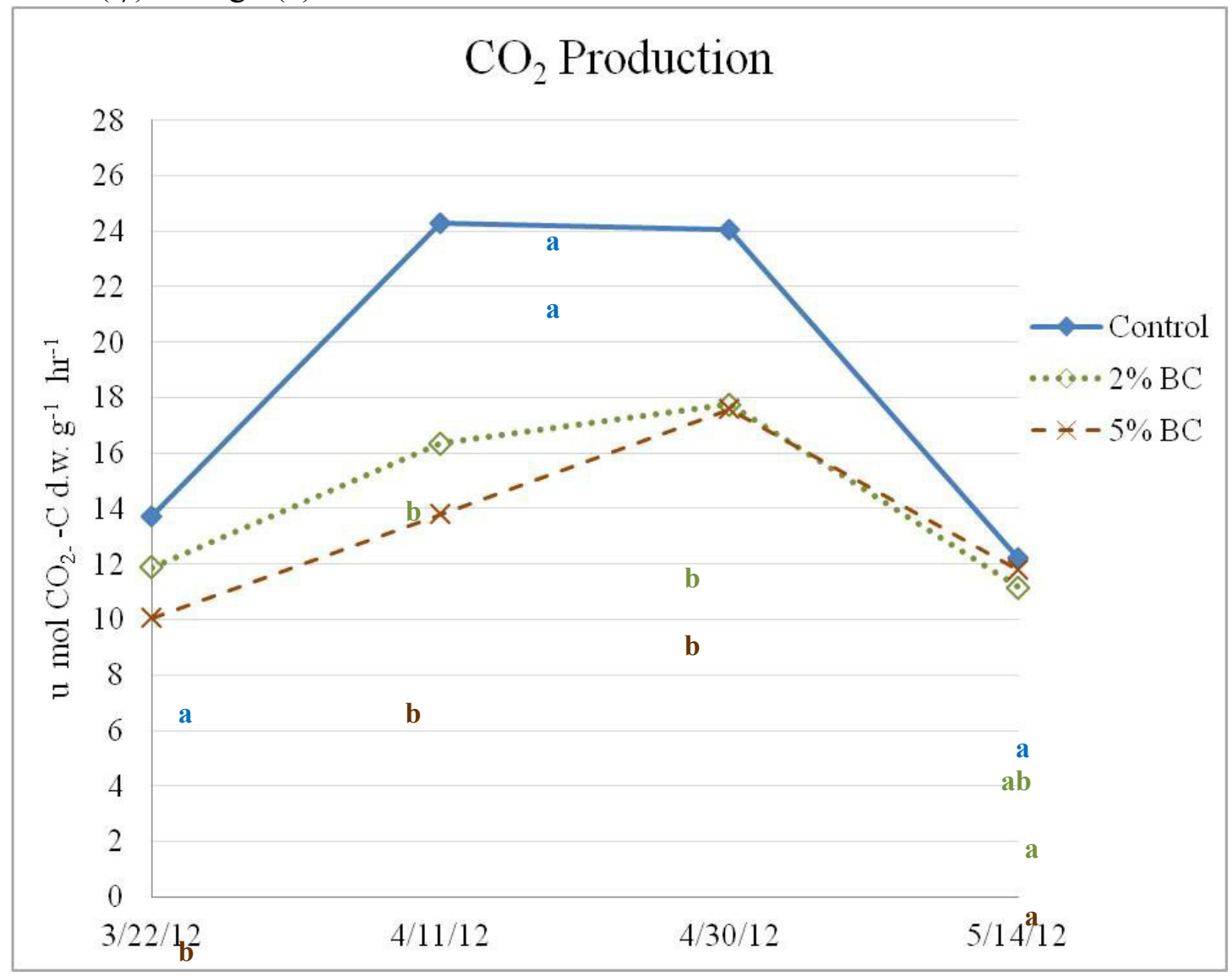


The preliminary test for measuring $\mathrm{CO}_{2}$ flux from the control soil and the biochar treated soils occurred prior to planting, but after $\mathrm{BC}$ had been incorporated into the soil for several weeks. The soil, however, was kept in a laboratory for weeks prior to incubation; the temperature $\mathrm{n}$ the laboratory was $\sim 72^{\circ} \mathrm{F}$. Colder environments tend to decrease microbial respiration. There was still a significant difference in the one way, between groups ANOVA at $\mathrm{p}<0.01: \mathrm{F}(2,9)=11.01$. The Tukey HSD Post hoc comparison shows the mean for the control group $(M=13.70 \pm 0.97)$ to be significantly greater than that of the $5 \% \mathrm{BC}$ group $(\mathrm{M}=11.88 \pm 1.28)$. There was no significant difference in means between the control group and 2\% BC group $(\mathrm{M}=10.06 \pm 1.03)$ or between the $2 \%$ and $5 \%$ BC treatments (Fig. 19).

Figure 19. $\mathrm{CO}_{2}$ flux from soils at $\left(\mathrm{t}_{\varnothing}\right)$ for Control, $2 \%$ and $5 \% \mathrm{BC}$ treatment groups prior to planting.

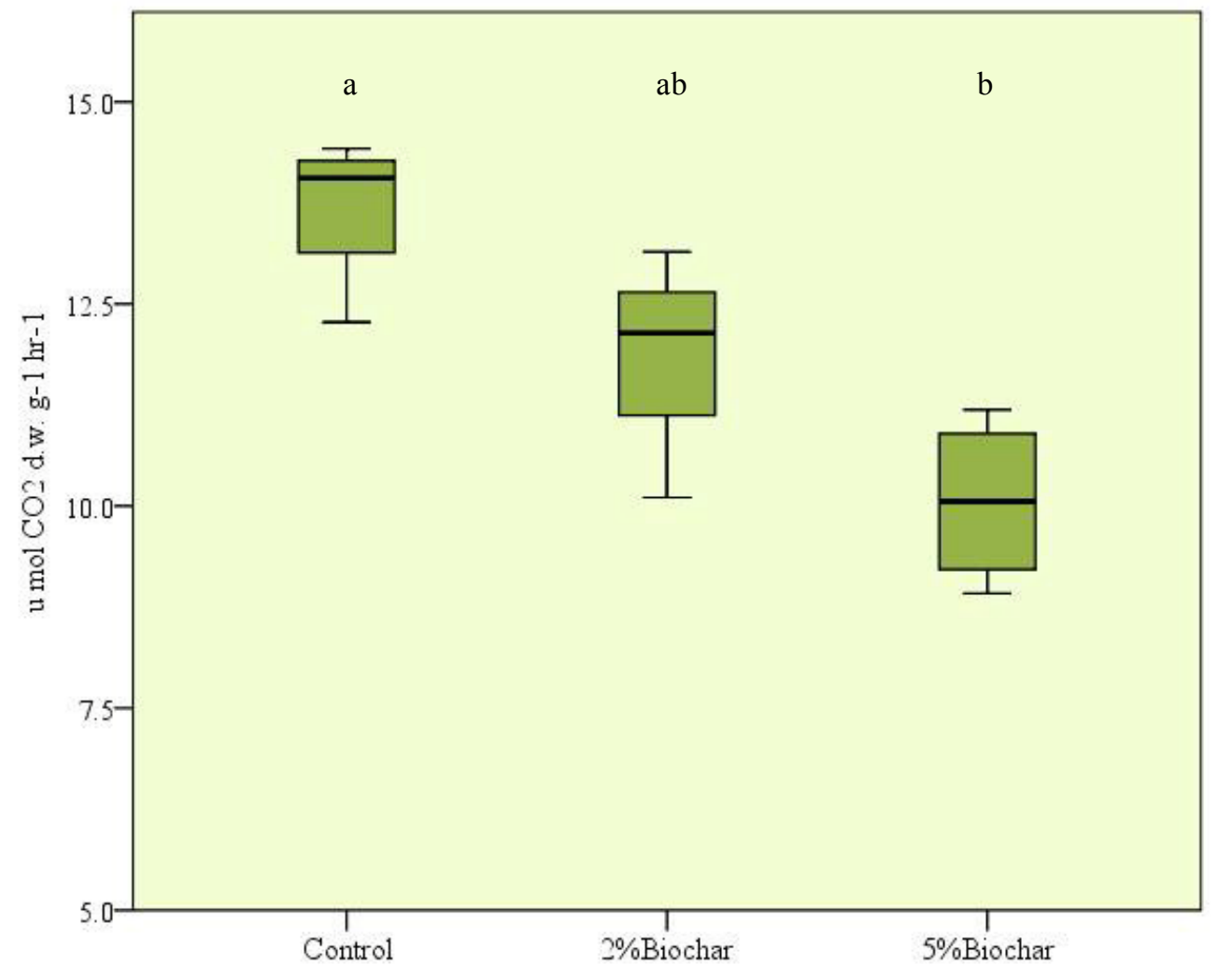


At $\left(t_{1}\right)$, the amount of $\mathrm{CO}_{2}$ flux from control soils was significantly greater than both $2 \%$ and $5 \%$ biochar treated soils at the p, 0.01 level: $\mathrm{F}(2,9)=9.77$. The Tukey-HSD Post hoc test indicated the mean score for the control group $(\mathrm{M}=24.28 \pm 5.61)$ was significantly larger than the $2 \% \mathrm{BC}$ group $(\mathrm{M}=16.35 \pm 1.99)$ and $5 \% \mathrm{BC}$ group $(\mathrm{M}=$ $13.79 \pm 1.12)$.

The $2 \%$ BC group did not differ from the 5\% BC group (Fig.20).

Figure 20. $\mathrm{CO}_{2}$ flux from soils at $\left(\mathrm{t}_{1}\right)$ for the Control, $2 \%$ and $5 \% \mathrm{BC}$ treatment groups.

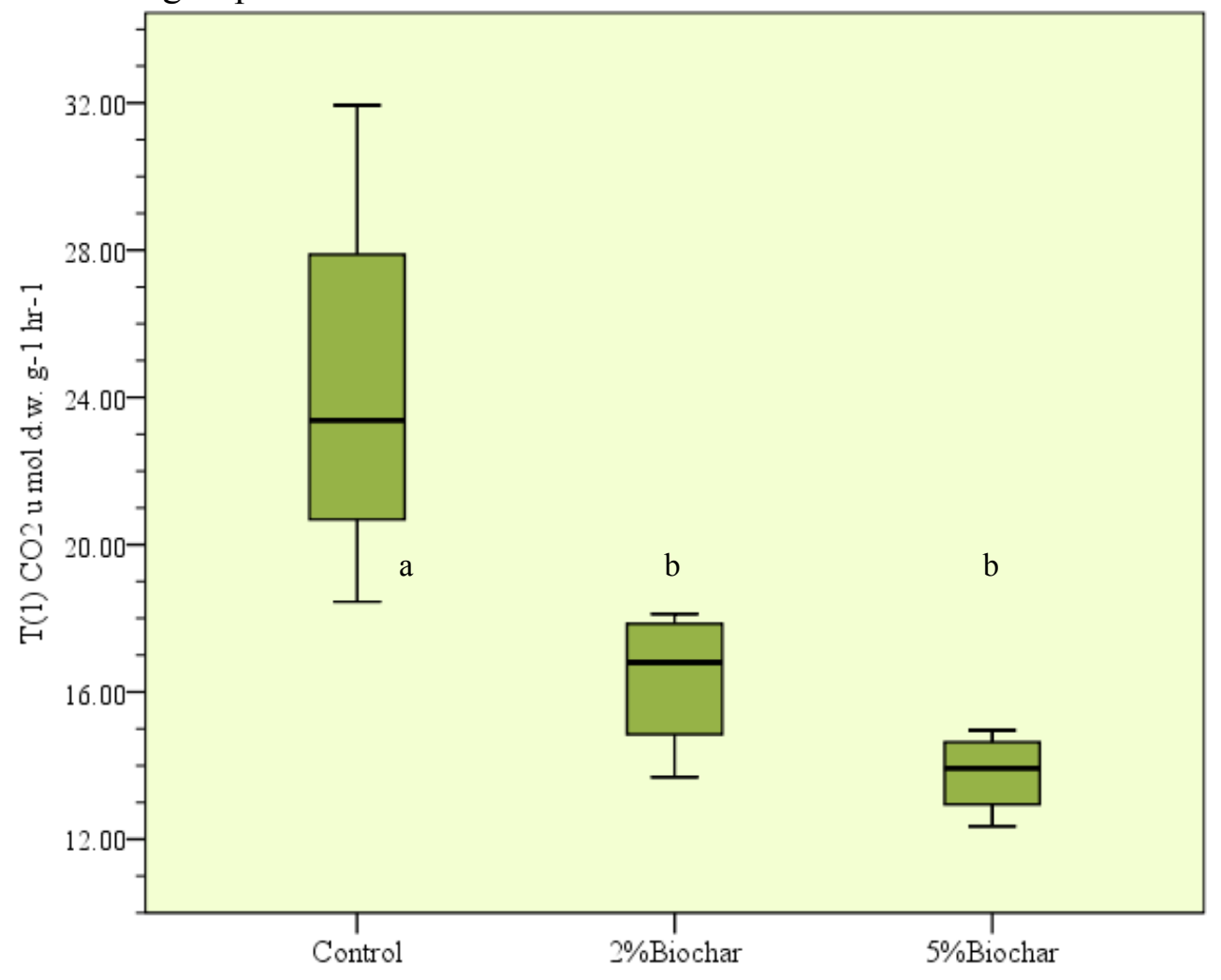

At $\left(t_{2}\right)$, the amount of $\mathrm{CO}_{2}$ flux from control soil was also significantly greater than both biochar treated soils at $\mathrm{p}<0.01, \mathrm{~F}(2,9)=8.37$. The Tukey-HSD Post hoc comparison test indicated the mean score for the control group $(\mathrm{M}=24.04 \pm 0.69)$ was 
significantly larger than the $2 \% \mathrm{BC}$ group $(\mathrm{M}=17.75, \mathrm{SD}=4.24)$ and $5 \% \mathrm{BC}$ group $(\mathrm{M}=$ $17.58 \pm 0.97$ ). The $2 \%$ and $5 \%$ treatments did not differ significantly (Fig. 21).

Figure 21. $\mathrm{CO}_{2}$ flux from soils at $\left(\mathrm{t}_{2}\right)$ for the Control, $2 \%$ and $5 \% \mathrm{BC}$ treatment groups.

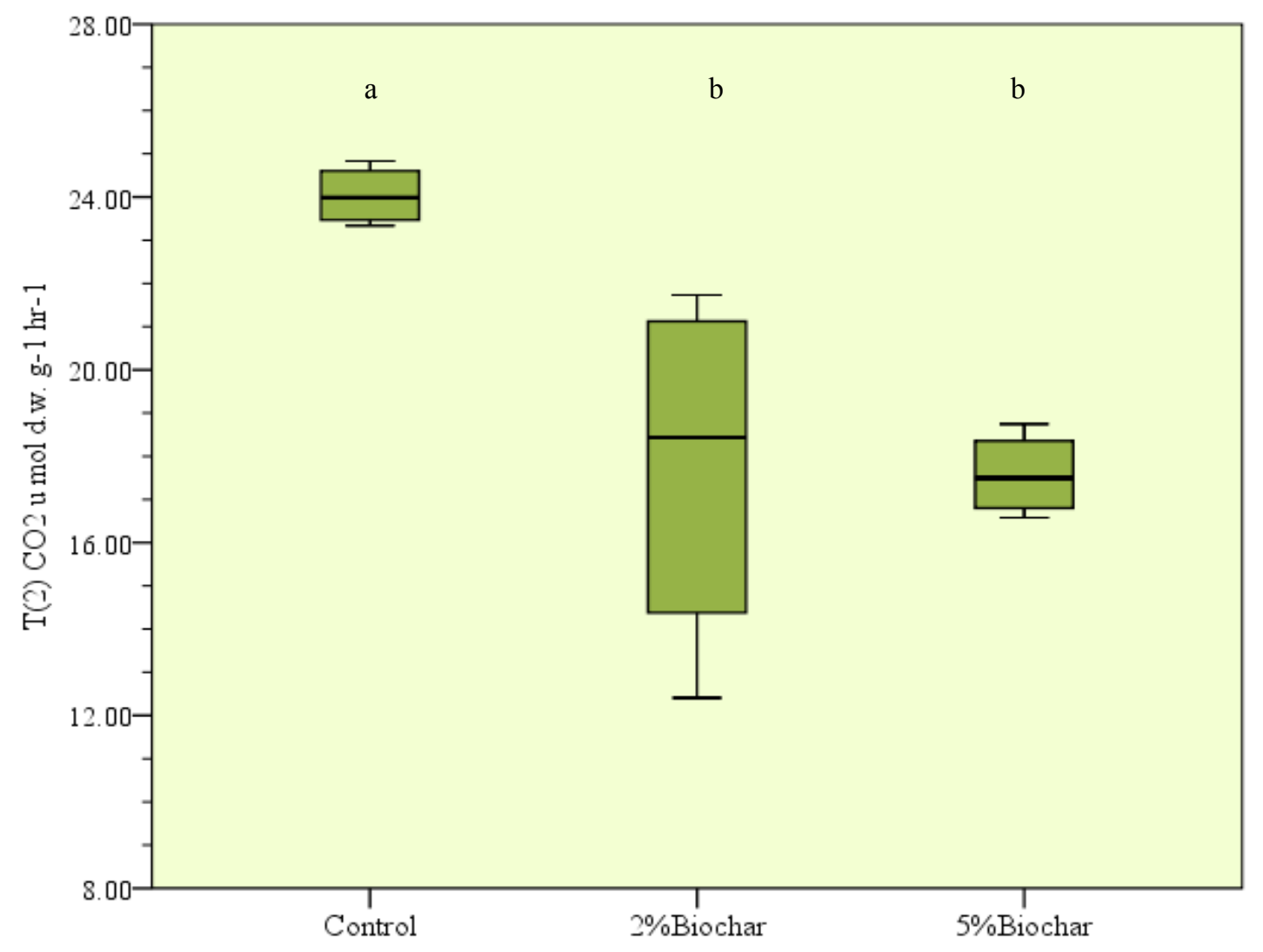

The final soil cores for $\mathrm{CO}_{2}$ flux were collected May 7, 2012. The ( $\mathrm{t}_{\mathrm{f}}$ ) samples could not be processed and incubated until six days after collection, unlike $\left(\mathrm{t}_{1}\right)$ and $\left(\mathrm{t}_{2}\right)$, which were incubated within 2 hours of sampling. The samples were stored in a laboratory at room temperature $\sim 72^{\circ} \mathrm{F}$. The results were similar to the flux seen in $\left(\mathrm{t}_{\varnothing}\right)$ soils, except without any significant differences between any of the groups. In both cases, there were no plants growing in the soil and therefore, less labile carbon from 
root exudates. The control Mean $=12.24 \pm 1.85$; the $2 \%$ BC Mean=11.16 \pm 2.62 , and the $5 \%$ BC Mean $=11.93 \pm 1.18$.

\section{Soil Quality}

Soil elemental analysis performed 4 weeks after biochar was incorporated into the soil yielded interesting results. As expected, the addition of biochar increased total $\mathrm{C}$ and total $\mathrm{N}$ in soil. As expected, many nutrients decreased in availability with the 5\% biochar application. In the $2 \% \mathrm{BC}$ soil, with the exception of $\mathrm{Na}, \mathrm{Mg}$, and $\mathrm{Zn}$, most nutrients were made more available; this was unexpected.

Table 3.

Elemental content and $\mathrm{pH}$ of soil and biochar amended soil four weeks after incorporation, prior to planting Phaseolus vulagaris L. (dry weight basis; mean and standard error, $\mathrm{N}=4$ ).

\begin{tabular}{|c|c|c|c|c|c|c|c|}
\hline \multicolumn{2}{|c|}{ Media } & $\begin{array}{l}\text { Total } \\
\text { C } \\
\end{array}$ & $\begin{array}{c}\text { Total } \\
\mathbf{N} \\
\end{array}$ & $\begin{array}{c}\text { Olsen } \\
\text { P }\end{array}$ & $\begin{array}{c}\text { Mehlich3 } \\
\text { K } \\
\end{array}$ & $\begin{array}{c}\text { Mehlich3 } \\
\mathrm{Na} \\
\end{array}$ & $\begin{array}{c}\text { Mehlich3 } \\
\text { Ca } \\
\end{array}$ \\
\hline \multirow[b]{2}{*}{ Soil } & \multirow[b]{2}{*}{$\begin{array}{l}\text { Mexn } \\
S D\end{array}$} & \multicolumn{2}{|c|}{---mg g-1 d.w.--- } & \multicolumn{4}{|c|}{------------mg kg-1 d.w.------------ } \\
\hline & & $\begin{array}{c}108.3 \mathrm{a} \\
5.21\end{array}$ & $\begin{array}{l}7.68 \\
0.19\end{array}$ & $\begin{array}{c}170.83 \mathrm{a} \\
8.81\end{array}$ & $\begin{array}{c}331.39 \mathrm{a} \\
8.56\end{array}$ & $\begin{array}{c}308.96 \mathrm{a} \\
4.07\end{array}$ & $\begin{array}{c}7235.43 a \\
356.15\end{array}$ \\
\hline $\begin{array}{l}2 \% \text { BC } \\
+ \text { soil }\end{array}$ & & $\begin{array}{c}137.53 b \\
18.56\end{array}$ & $\begin{array}{l}8.45 \\
0.97\end{array}$ & $\begin{array}{c}180.63 \mathrm{a} \\
8.89\end{array}$ & $\begin{array}{c}341.61 \mathrm{a} \\
7.29\end{array}$ & $\begin{array}{c}308.96 a \\
7.76\end{array}$ & $\begin{array}{c}7289.74 a \\
229.64\end{array}$ \\
\hline \multicolumn{2}{|l|}{$\begin{array}{l}5 \% \mathrm{BC} \\
+ \text { soil }\end{array}$} & $\begin{array}{c}175.13 \mathrm{c} \\
10.64\end{array}$ & $\begin{array}{l}8.38 \\
0.54\end{array}$ & $\begin{array}{c}172.45 \mathrm{a} \\
7.02\end{array}$ & $\begin{array}{c}305.2 \mathrm{~b} \\
15.63\end{array}$ & $\begin{array}{c}264.94 b \\
9.34\end{array}$ & $\begin{array}{c}5824.3 b \\
190.60\end{array}$ \\
\hline \multicolumn{2}{|c|}{ Media } & $\begin{array}{c}\text { Mehlich3 } \\
\text { Mg }\end{array}$ & $\begin{array}{c}\text { Mehlich3 } \\
\text { Fe }\end{array}$ & $\begin{array}{c}\text { Mehlich3 } \\
\text { Cu }\end{array}$ & $\begin{array}{c}\text { Mehlich3 } \\
\text { Zn }\end{array}$ & $\begin{array}{c}\text { Mehlich3 } \\
\text { Mn }\end{array}$ & pH \\
\hline \multicolumn{8}{|c|}{-----------mg kg-1 d.w.-------------- } \\
\hline Soil & $\begin{array}{c}\text { Mean } \\
S D\end{array}$ & $\begin{array}{c}260.80 \mathrm{a} \\
3.46\end{array}$ & $\begin{array}{c}60.14 \mathrm{a} \\
1.34\end{array}$ & $\begin{array}{c}1.07 \mathrm{a} \\
0.04\end{array}$ & $\begin{array}{c}13.31 \mathrm{a} \\
1.93\end{array}$ & $\begin{array}{c}5.19 \mathrm{a} \\
0.18\end{array}$ & 8.05 \\
\hline $\begin{array}{l}2 \% \text { BC } \\
+ \text { soil }\end{array}$ & & $\begin{array}{c}257.15 \mathrm{a} \\
3.70\end{array}$ & $\begin{array}{c}63.41 \mathrm{~b} \\
1.85\end{array}$ & $\begin{array}{c}1.14 \mathrm{a} \\
0.06\end{array}$ & $\begin{array}{c}11.66 \mathrm{a} \\
0.24\end{array}$ & $\begin{array}{c}5.39 \mathrm{a} \\
0.03\end{array}$ & 8.19 \\
\hline $\begin{array}{l}5 \% \mathrm{BC} \\
+ \text { soil } \\
\end{array}$ & & $\begin{array}{c}199.18 b \\
7.08 \\
\end{array}$ & $\begin{array}{c}40.83 \mathrm{c} \\
1.27 \\
\end{array}$ & $\begin{array}{c}0.82 \mathrm{~b} \\
0.04\end{array}$ & $\begin{array}{c}8.70 \mathrm{~b} \\
0.27 \\
\end{array}$ & $\begin{array}{c}4.41 \mathrm{~b} \\
0.28 \\
\end{array}$ & 8.22 \\
\hline
\end{tabular}

* Statistically significant difference calculated at $p<0.05$ 
Table 4.

Elemental content and $\mathrm{pH}$ of soil and biochar amended soil at harvest (dry weight basis; mean and standard error, $\mathrm{N}=4$ ).

\begin{tabular}{|c|c|c|c|c|c|}
\hline Media & $\begin{array}{c}\text { Olsen } \\
\mathbf{P}\end{array}$ & $\begin{array}{c}\text { Mehlich3 } \\
\text { K }\end{array}$ & $\begin{array}{c}\text { Mehlich3 } \\
\text { Na }\end{array}$ & $\begin{array}{c}\text { Mehlich3 } \\
\text { Ca }\end{array}$ & $\begin{array}{c}\text { Mehlich3 } \\
\text { Mg }\end{array}$ \\
\hline $\begin{array}{c}\text { Mean } \\
S D\end{array}$ & $\begin{array}{c}285.94 \mathrm{a} \\
63.67\end{array}$ & $\begin{array}{c}145.35 \mathrm{a} \\
11.31\end{array}$ & $\begin{array}{c}282.45 \mathrm{a} \\
12.90\end{array}$ & $\begin{array}{c}3537.99 a \\
393.77\end{array}$ & $\begin{array}{c}177.04 \mathrm{a} \\
2.59\end{array}$ \\
\hline $\begin{array}{l}2 \% \mathrm{BC} \\
+ \text { soil }\end{array}$ & $\begin{array}{c}225.93 b \\
39.16\end{array}$ & $\begin{array}{c}176.01 \mathrm{a} \\
22.78\end{array}$ & $\begin{array}{c}274.16 \mathrm{a} \\
12.50\end{array}$ & $\begin{array}{c}3264.46 \mathrm{a} \\
315.93\end{array}$ & $\begin{array}{c}161.73 b \\
4.66\end{array}$ \\
\hline $\begin{array}{l}5 \% \mathrm{BC} \\
+ \text { soil }\end{array}$ & $\begin{array}{c}180.14 b \\
5.03\end{array}$ & $\begin{array}{c}183.82 \mathrm{a} \\
24.63\end{array}$ & $\begin{array}{c}284.28 \mathrm{a} \\
10.80\end{array}$ & $\begin{array}{c}2509.97 b \\
317.55\end{array}$ & $\begin{array}{c}133.06 \mathrm{c} \\
10.79\end{array}$ \\
\hline Media & $\begin{array}{c}\text { Mehlich3 } \\
\text { Fe }\end{array}$ & $\begin{array}{c}\text { Mehlich3 } \\
\mathrm{Cu} \\
\end{array}$ & $\begin{array}{c}\text { Mehlich3 } \\
\text { Zn } \\
\end{array}$ & $\begin{array}{c}\text { Mehlich3 } \\
\text { Mn }\end{array}$ & pH \\
\hline $\begin{array}{c}\text { Mean } \\
\text { SD }\end{array}$ & $\begin{array}{c}45.07 \mathrm{a} \\
5.67\end{array}$ & $\begin{array}{c}0.87 \mathrm{a} \\
0.05\end{array}$ & $\begin{array}{c}8.55 \mathrm{a} \\
0.25\end{array}$ & $\begin{array}{c}3.98 \mathrm{a} \\
0.64\end{array}$ & 8.04 \\
\hline $\begin{array}{l}2 \% \mathrm{BC} \\
+ \text { soil }\end{array}$ & $\begin{array}{c}44.64 \mathrm{a} \\
7.20\end{array}$ & $\begin{array}{c}0.83 \mathrm{a} \\
0.03\end{array}$ & $\begin{array}{c}7.78 \mathrm{a} \\
0.41\end{array}$ & $\begin{array}{c}4.15 \mathrm{a} \\
0.66\end{array}$ & 8.15 \\
\hline $\begin{array}{l}5 \% \mathrm{BC} \\
+ \text { soil } \\
\end{array}$ & $\begin{array}{c}36.12 \mathrm{a} \\
-4.68\end{array}$ & $\begin{array}{c}0.70 \mathrm{~b} \\
0.08\end{array}$ & $\begin{array}{c}6.57 \mathrm{~b} \\
0.27\end{array}$ & $\begin{array}{c}3.45 \mathrm{a} \\
0.49\end{array}$ & $\underline{8.18}$ \\
\hline
\end{tabular}

* Statistically significant difference calculated at $p<0.05$ 


\section{DISCUSSION}

\section{Biochar and Germination}

The primary hypothesis driving this research experiment was that the application of Melaleuca quinquenervia biochar at a lower rate would be beneficial for soil quality, plant growth, and $\mathrm{CO}_{2}$ reduction, while the higher application rate would harm plant growth, but further reduce $\mathrm{CO}_{2}$ emissions. This broad hypothesis was proven true in some aspects and false in others.

Melaleuca quinquenervia biochar analysis showed similar characteristics to other woody biomass biochars produced at $350^{\circ} \mathrm{C}$. It would have been useful to submit biochar to further analysis for a more comprehensive understanding of the elemental composition, but funding was limited for this form of analysis. The $\mathrm{pH}$ of Melaleuca quinquenervia biochar was slightly higher than amendments usually applied to calcareous agricultural soils in southeastern Florida. The fact remains that several farmers in the region are already utilizing $\mathrm{BC}$ from similar feedstock and it is critical to evaluate the potential impact its application may have on soil fertility and crop production.

Seed germination of Phaseolus vulgaris L. yielded interesting results. It was anticipated germination would be equal across all groups, yet the control group had the lowest rate of seedling emergence. Soil moisture, temperature, and adequate lighting are critical to successful seed germination. In this case, both temperature and light intensity and exposure were equal among all treatments. The ability of biochar to retain moisture could have played a role in germination success. This idea is supported by the fact that the 5\% treatment group had the highest germination rate, 
followed by the $2 \%$ treatment group, with the control group having the least emerging plants.

\section{Biochar and Plant Growth}

Plant mortality in the study was likely the result of increasingly high temperatures in the greenhouse over the summer months. While Phaseolus vulgaris is selectively grown in Florida for its heat tolerance, the temperature in the experimental greenhouse is not controlled and airflow is minimal, making conditions more stressful for non native, agricultural crops. Plant mortality was not attributed to the addition of biochar since all groups experienced equal losses.

There was a statistically significant difference in plant response between the control group and both biochar additions. Plant production in biochar amended soil was not enhanced, rather, growth was inhibited. Above ground biomass dry weight $(\mathrm{g})$ in the control group $(\mathrm{M}=8.21, \mathrm{SD}=0.55)$ was almost double that of the biochar treatment groups, $2 \% \mathrm{BC}$ group $(\mathrm{M}=4.24, \mathrm{SD}=1.12)$ and $5 \% \mathrm{BC}$ group $(\mathrm{M}=4.09, \mathrm{SD}=$ 0.85). The differences in weight can be primarily connected primarily to pod production, not in terms of count, but overall dry weight $(\mathrm{g})$. The control group produced pods weighing over four times that of the $2 \%$ and $5 \%$ biochar treatment groups, respectively, $\mathrm{M}=4.25, \mathrm{SD}=0.66$ for the control group, $\mathrm{M}=0.78, \mathrm{SD}=0.47$ for the $2 \% \mathrm{BC}$ group, and $\mathrm{M}=0.54, \mathrm{SD}=0.45$ for the $5 \% \mathrm{BC}$ group.

The differences in pod production are remarkable considering the plants in the control group and $\mathrm{BC}$ treatments had leaf areas and specific leaf areas that were not statistically different. Specific leaf area is usually correlated with photosynthetic potential. Harris (1992) explains root-shoot ratio decreases tend to be a response to 
more favorable conditions. While the control root shoot ratio was slightly lower, there was no significant difference among the three groups, meaning the plants did not allocate more growth to roots or shoot in any particular group.

As hypothesized, $M$ quinquenervia biochar treatment at $5 \%$ led to lower plant productivity than the $2 \%$ treatment, but not at a statistically significant level. There was much variation in the $5 \%$ group, as one plant responded better than most plants in the $2 \%$ group in terms of plant height, leaf area, and length of pods produced. This leads me to believe there is hope for plants grown in $\mathrm{BC}$ amended soil, but more research must be conducted to analyze why plant productivity was inhibited. Lower leaves from most of the 5\% group were stressed, chlorotic, and deformed.

\section{Biochar and Soil Quality}

I hypothesized the application of M. quinquenervia biochar would reduce available nutrients in the soil. A significant reduction in all available nutrients held true for the 5\% biochar application. Mehlich III soil test prior to planting showed the decrease occurred as quickly as four weeks after BC was incorporated into the soil. These nutrient deficits may explain why the plants in the $5 \%$ group reacted so poorly to the high $\mathrm{BC}$ application rate. However, the decrease in available nutrients did not occur in the $2 \%$ treatment group.

Four weeks after BC incorporation into soil, the $2 \%$ treatment group showed an increase in all available nutrients with the exception of $\mathrm{Zn}$ and $\mathrm{Mg}$; however, only increases in $\mathrm{Fe}$ and $\mathrm{P}$ were statistically significant. Novak et al. $(2009 ; 2010)$ 
showed similar results after incorporating BC into soil and incubating for 67 days. In other studies, nutrient increases have been attributed to the direct application of biochar, which inherently retains some characteristics from the feedstock material. In this study it would be inaccurate to make that connection, as the increase did not hold true for the higher $\mathrm{BC}$ treatment group. In this case, it seems $\mathrm{BC}$ indirectly affected soil nutrient retention through an increase in exchangeable cations, as has been the case in many other biochar studies (Lehmann 2003; Jha 2010; Novak 2009).

At $\mathrm{T}(\mathrm{f})$, the nutrient levels for the $5 \%$ group remained lower than the two other groups, with the exception of $\mathrm{K}$ and $\mathrm{Na}$, which both had values higher than the control and $2 \%$ group. In the $2 \% \mathrm{BC}$ treated soil, available nutrients dropped below the control levels with the exception of $\mathrm{Mn}$ and $\mathrm{K}$. Evaluation of the change in most nutrients from $T(1)$ to $T(f)$ showed the control group and $2 \%$ group had similar quantitative losses. If the availability of most nutrients were similar or even greater in the $2 \% \mathrm{BC}$ group, the question remains as to why there would not be similar levels of plant production.

After thorough research on zinc deficiencies, it appears the decrease in $\mathrm{Zn}$ availability was the likely cause of stunted plants from the biochar group. While the decrease in available $\mathrm{Zn}$ was slight, even a minimal decrease in a micronutrient can result in serious growth impediment. Zn deficient plants tend to be stunted due to a reduction in root growth. Older or lower leaves display browning or bronzing; see Image 5. In the case of zinc deficient beans, leaves may display a crinkled appearance and pod set may be poor. The BC treated plants that did best had slightly higher levels of available $\mathrm{Zn}$ when compared to those that did worse. 


\section{Biochar and Soil Respiration}

I also hypothesized M. quinquenervia biochar mixed with soil would reduce $\mathrm{CO}_{2}$ emissions when compared to control soils. There were mixed results. There was a significant difference between the control group and 5\% treatment prior to planting, but no difference between the control and $2 \%$ treatment. $\mathrm{CO}_{2}$ measured twice throughout the growing process, showed a statistically significant difference between the control group and both biochar treatments.

At $\mathrm{T}(\mathrm{f})$, the soil was not incubated immediately and remained in a laboratory for several days prior to processing. This was not intentional, rather, an unfortunate consequence. On the night I harvested the plants, I would not have access to the lab with purging equipment and the gas chromatograph for two full days. I was also occupied in several other laboratories measuring other plant production parameters and processing soil samples at the USDA-ARS Miami, Fl.

It is well documented temperature decreases lower microbial activity in soils and thereby reduce soil respiration. Study by Yuste et al. (2010) evaluated soil respiration from soils incubated at two temperatures, $10 \mathrm{C}$ and $30 \mathrm{C}$. At warmer temperatures soil respiration was significantly greater, however, there was an exponential decrease in respiration over a short period of time (40 days). Their research attributes the decline to the rapid decay of the labile $\mathrm{C}$ pool in warmer soils. Microbial respiration from soil incubated at $10 \mathrm{C}$ also decreased exponentially, but over a longer period of time (120 days). While $\mathrm{BC}$ addition primarily supplies fixed carbon, the presence of compost in the garden soil easily contributed to an easily decomposable $\mathrm{C}$ source. 
A study by Steinbeiss et al (2009) using two different biochars showed glucose derived biochar decreased microbial populations significantly while yeast derived biochar had little effect on microbial population. Regardless of whether BC is added to soil, many other factors play a role in soil respiration. Plant exudates from roots contribute to

decomposable $\mathrm{C}$ in the form of simple sugars and amino acids. Plants from the control group had the highest productivity and denser root systems, meaning they could have easily increased soil respiration through healthier plant activity. It is difficult to assess whether $\mathrm{BC}$ has the potential to reduce $\mathrm{CO}_{2}$ flux at varying temperatures in the long term using this study, but short term reduction at warmer temperatures is evident. 


\section{CONCLUSION}

The addition of biochar to soils used for agricultural production is a delicate matter. While many researcher praise biochar as being a cure all for the climate change dilemma, much research still remains to be done. Custom engineered biochars for localized areas is a key research area, as not all soils react the same to incorporation. Furthermore, the rate of application must also be taken into consideration.

Biochar feedstock and pyrolysis methods vary widely. In the case of this study, Melaleuca quinquenervia pyrolyzed at $350 \mathrm{C}$ proved to be a good choice. The presence of this invasive tree allows for a great supply of unneeded biomass. While Phaseolus vulgaris L. production was harmed by the incorporation of $\mathrm{BC}$ at $5 \%$, it is evident this application rate is not beneficial. However, the $2 \%$ application did increase the availability of nutrients in the soil. In this case, the decreases in $\mathrm{Zn}$ may have proved detrimental, but careful monitoring of micronutrient levels can result in better plant production. The application of organic fertilizer with micronutrients can enhance plant growth where $\mathrm{BC}$ is applied.

More research should be conducted to evaluate how 2\% application of $M$. quinquenervia BC will affect other agricultural crops commonly grown in southeastern Florida. Should the biochar produced from M. quinquenervia parent material prove harmful to other crops, perhaps we should look elsewhere for uses of the amendment. Western soils that are highly acidic could benefit more from the elevated $\mathrm{pH}$. If the biochar with micronutrient supervision proves useful for local agricultural production, research into how long the beneficial properties of $\mathrm{BC}$ remain in soil should also be carried out. 


\section{REFERENCES}

Arrow, Kenneth, B. Bolin, R. Costanza, P. Dasgupta, C. Folke, C. S. Holling, B. Jansson, S. Levin, K. Maler, C. Perrings, and D. Pimentel (1995). Economic growth, carrying capacity, and the environment. Science. $268: 520-521$

Baumert, K. A., Herzog, T., Pershing J. (2005). "Navigating the Numbers Greenhouse Gas Data and International Climate Policy". World Resources Institute, 85-86. $<$ http://pdf.wri.org/navigating_numbers.pdf $>$

Beesley, Luke, Marmiroli, Marta. (2011). "The immobilisation and retention of soluble arsenic, cadmium and zinc by Biochar." Environmental Pollution 159: 474-480

Bradford MA, Davies CA, Frey SD, Maddox TR, Melillo JM, Mohan JE, Reyno

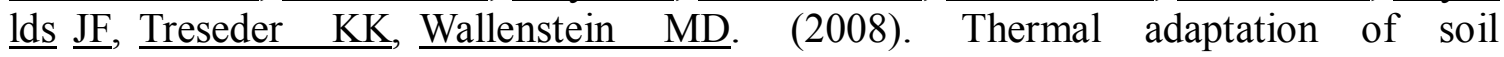
microbial respiration to elevated temperature. Ecological Letters 11 (12):1316-27.

Chan, K.Y., L. van Zweiten, I. Meszaros, A. Downie, S. Joseph. (2008). "Using poultry litter biochars as soil amendments." Australian Journal of Soil Research. 46: $437-444$

Chen, B., Z. Chen, and S. Lv. (2011). "A novel magnetic biochar efficiently sorbs organic pollutants and phosphate." Bioresource Technology 102 :716-723

Chrost, R.J., and Krambeck H.J. (1986). Flourescence correction for measurements of enzyme activity in natural water using methylumbelliferyl-substrates. Arch.Hydrobiol. 106(1):79-90.

Chu, S. and A. Majumdar. (2012). Opportunities and challenges fr a sustainable energy future. Nature. 448:294-303.

Clough, Tim J. and L. M. Condron. (2010)"Biochar and the Nitrogen Cycle: Introduction." Journal of environmental quality 39 (4) : 1218-23.

Costanza, R., R. d'Arge, R. de Groot, S. Farber, M. Grasso, B. Hannon, K. Limburg, S. Naeem, R.V. O'Neill, J. Paruelo, R.G. Raskin, P. Sutton \& M. van den Belt. (1997). The value of the world's ecosystem services and natural capital. Nature. 387:253-260.

Coyne, Mark. (1999). Soil Microbiology: An exploratory approach. Delmar Publishing. Albany, New York.

DeFries, R.S. et al. (1999).Combining satellite data and biogeochemical models to estimate global effects of human-induced land cover change on carbon emissions and primary productivity. Global Biogeochemical Cycle. 13: 803-815.

Doran, John W. and M. R. Zeiss. (2000). Soil health and sustainability: managing 
the biotic component of soil quality. Applied Soil Ecology. 15 :3-11

Dray, F.A. , B.C. Bennett, and T.D. Center. (2006). Invasion history of Melaleuca quinquenervia (cav.) S.T. Blake in Florida. Castanea. 71(3): 210-225.

Elradashi, M.S. (2008). Selection of an appropriate phosphorus test for soils. NRCS- USDA, Soil Survey Lab. (\#395). Lincoln, NE.

FAO. Soil biota and biodiversity: The "root" of sustainable development. www.fao.org/ag/AGL/agll/soilbiod/default.htm

FAOSTAT. (2009). Statistical Database Domain on Fertilizers: Resource STAT- Fertilizers. Food and Agriculture Organisation of the United Nations Rome, Italy. $<$ http://faostat.fao.org/site/575/default.aspx\#anchor $>$

Feder, Gershon and G.T. O'Mara. (1981). Farm Size and the Diffusion of Green Revolution Technology. Economic Development and Cultural Change. 30 (1):5976.

Gleissman, Steven R. (1998). Agroecology: Ecological processes in sustainable agriculture. Ann Arbor Press. Chelsea, Michigan.

Harris, Richard W. (1992). Root shoot ratios. Journal of Arboriculture.18 (1): 39-42.

Houghton, R. A. and Hackler, J. L. (2001).Carbon flux to the atmosphere from landuse changes:1850-1990. U.S. Department of Energy, Oak Ridge National Laboratory, Oak Ridge, Tennessee, U.S.

IPCC (2001.) Climate Change 2001: Impacts, Adaptations and Vulnerabilities. Technical Summary. A report of Working Group II of the Intergovernmental Panel on Climate Change

Jackson, M.L. (1967). Soil chemical analysis. Prentice Hall of India (Pvt.) Ltd., New Delhi.

Janzen, H. H., Desjardins R.L. (1999). The Health of Our Air: Towards Sustainable Agriculture in Canada. Agriculture and Agri-Food Canada Research Branch, Canada.

Jha, Pramod et al. (2010). Biochar in agriculture - prospects and related implications." Current Science. 99 (9) :1218-1225.

Kammann, C., S Ratering, C. Eckhard, and C. Muller. (2012). Biochar and Hydrochar Effects on Greenhouse Gas (Carbon Dioxide, Nitrous Oxide, and Methane) fluxes from Soils. Journal of Env Quality. 41:1052-1066.

Karlen, D.L., M. J. Mausbach, J. W. Doran, R. G. Cline, R. F. Harris, and G. E. 
Schuman. (1997). Soil Quality: A Concept, Definition, and Framework for Evaluation. Soil Science Society of America. 61:4-10.

Lal, R. (1997). Residue management, conservation tillage and soil restoration for mitigating greenhouse effect by CO2 -enrichment. Soil Tillage Res. 43 :81-107.

Lal, R. and J. P. Bruce. (1999). The potential of world cropland soils to sequester C and mitigate the greenhouse effect. Environ. Sci. Policy 2:177-186.

Langeland K.A., Cherry H.M.. (2008). "Identification and Biology of Nonnative Plants in Florida's Natural Areas". University of Florida-IFAS. SP 257 $<$ http://plants.ifas.ufl.edu/misc/pdfs/SP257/Melaleuca_quinquenervia(SP257100).pdf $>$

Langeland, K. A., J. A. Ferrell, B. Sellers, G. E. MacDonald, and R. K. Stocker. (1997). Integrated Management of Nonnative Plants in Natural Areas of Florida. University of Florida- Institute of Food and Agricultural Sciences. SP $242 .<$ http:// edis.ifas.ufl.edu.>

Lehmann, J. J. Pereira da Silva , C. Steiner, T. Nehls, W. Zech, and B. Glaser. (2003). Nutrinet availability and leaching in an archaeological Anthrosol and Ferrosol of the Central Amazon Basin: fertilizer, manure, and charcoal amendments.Plant Soil. 249: 343-347.

Lehmann J. (2007). Bio-energy in the black. Frontiers Ecology and Environment 5 :381-387.

Matovic, Darko. (2011). "Biochar as a viable carbon sequestration option: Global and Canadian perspective." Energy. 36 :2011-2016.

Millennium Ecosystem Assessment. (2005). "Ecosystems and Human Well-being: Biodiversity Synthesis.” World Resources Institute, Washington, DC.

Novak, J.M., I. Lima, B. Xing, J.W. Gaskin, C. Steiner, K.C. Das, M. Ahmedna, D. Rehrah, D.W. Watts, W.J Busscher, and H. Schomberg. (2009). "Characterization of designer biochar produced at different temperatures and their effects on a loamy sand." Annals of Environmental Science, 3:195-206

Novak, J.M., W.J Busscher, D.L Laird, M. Ahmedna, D.W. Watts, and M.A.S. Niandou. (2009). "Impact of Biochar Amendment on Fertility of a Southeastern Coastal Plain Soil." Soil Science 174(2) :105-12.

Olsen, S.R., C.L. Cole, P.S. Watanabe and L.A. Dean. (1954). Estimation of available phosphorus in soils by extraction with sodium bicarbonate. USDA Circ. 939. 
Petrini, Carlo. (2005). Slow food nation: Why our food should be good, clean, and fair.Rizzoli International. New York, New York.

Reicosky, D.C., W.D Kemper, G.W. Langdale, C.L Douglas Jr. and P.E Rasmussen. (1995). Soil organic matter changes resulting from tillage and biomass production. Journal of Soil and Water Conservation. 50 (3) :253-261.

Rekha, S.N and R.P. Naik. (2006). Pesticide residue in organic and conventional food- risk analysis. Chemical Health and Safety. November/December: 12-19.

Scialabba, Nadia El Hage et al. (2010). "Organic agriculture and climate change." Renewable Agriculture and Food Systems. 25(2) :158-169.

Sinsabaugh R.L., Findlay S., Franchini P., ,Fischer D. (1997). Enzymatic Analysis of Riverine Bacterioplankton Production. Limnology and Oceanography 42(1) :29-38.

Smith, J. L., H.P Collins, V.L Bailey. (2010). "The effect of young biochar on soil respiration." Soil Biology \& Biochemistry 42 :2345-2347

Smith, W. N., Desjardins, R. L., and Pattey, E. (2000). The net flux of carbon from agricultural soils in Canada from 1970-2010. Global Change Biol. 6: 557- 568.

Sombroek WM, Ruivo ML, Fearnside PM, Glaser B, Lehmann J. (2003) Amazonian dark earths as carbon stores and sinks. "Amazonian Dark Earths: Origins, properties, management.” Dordrecht: Kluwer Acad. Publ. 125-139.

Steinbeiss, S., G. Gleixner, and M. Antonietti. (2009). Effect of biochar amendment on soil carbon balance and microbial activity. Soil Biology and Biogeochemistry. 41: 1301-1310.

USDA, Natural Resources Conservation Service. (2001). Soil Biota. Rangeland Soil Quality Sheet 8. 1-2. <http://soils.usda.gov/sqi>

Vaccari, F. P., et al. (2011) "Biochar as a Strategy to Sequester Carbon and Increase Yield in Durum Wheat." Agronomy. 34 :231-238.

Van Driesche, R.B. Blossey, M. Hoddle, S. Lyon, and R. Reardon.(2002). Biological control of invasive plants in the eastern United States. USDA Forest Service. Publication FHTET-2002-04: 117-130.

Van Zwieten, L., S. Kimber, S. Morris, A. Downie, J.Rust, S. Joseph, and A. Cowie. (2010). "Effects of Biochar from Slow Pyrolysis of Papermill Waste on Agronomic Performance and Soil Fertility." Plant Soil 327: 235-246. 
Warnock, D.D., Lehmann, J., Kuyper, T.W., Rillig, M.C. (2007). "Mycorrhizal responses to biochar in soil - concepts and mechanisms". Plant Soil 300 :9-20.

Warnock, Daniel D., et al. (2010). "Influences of Non-Herbaceous Biochar on Arbuscular Mycorrhizal Fungal Abundances in Roots and Soils: Results from Growth- Chamber and Field Experiments." Applied Soil Ecology 46.(3) :450-6.

Wood, A.J. and Roper, J. (2000) "A Simple and Nondestructive Technique for Measuring Plant Growth and Development." American Biology Teacher. 62: 215-17.

Yuste, Curiel J., S. Ma, and D.D. Baldocchi.. (2010) Plant-soil interactions and acclimation to temperature of microbial-mediated soil respiration may affect predictions of soil CO2 efflux. Biogeochemistry 98:127-138

Zhang, A-F, G-X Pan, and L-Q Li. (2009). "Biochar and the Effect on C Stock Enhancement, Emission Reduction of Greenhouse Gases and Soil Reclaimation." Journal of Agro-Environment Science 28(12) :2459-63. 